\title{
Synthesis [1-(4-acetylphenyl)-3-(2-methylphenyl)]triazene: NMR, Vibrational, X-ray Crystallography Characterization with HF/ DFT Studies
}

\author{
Reza Soleymani ${ }^{1 *}$, Abolfazl Aghaei ${ }^{2}$, Elahe Abdolahi Shahvali ${ }^{3}$ \\ ${ }^{1}$ Young Researchers and Elite Club, Shahr-E-Rey Branch, Islamic Azad University, \\ Tehran, Iran. \\ ${ }^{2}$ Faculty of Chemistry, Tarbiat Moallem University, Tehran, Iran. \\ ${ }^{3}$ Department of Chemistry, Dezful Branch, Islamic Azad University, Dezful, Iran.
}

[1-(4-acetylphenyl)-3-(2-methylphenyl)]triazene (AMT) was synthesized by experimental methods, its chemical and spectrometric properties were studied by FT-IR, FT-Raman, ${ }^{1} \mathrm{H}-$ NMR, ${ }^{13} \mathrm{C}$-NMR and X-ray single-crystal diffraction methods. The obtained results showed that this structure has orthorombic system with space group of pbca and eight molecules in unit cell. Its unit cell parameters comprise $\mathrm{a}=8.0665(2), \mathrm{b}=8.0019(2)$ and $\mathrm{c}=21.5249(5)$. Then molecular number of [1-(4-acetylphenyl)-3-(2-methylphenyl)]triazene (AMT) structure has been studied by HF/DFT methods. However, FT-IR, FT-Raman, ${ }^{1} \mathrm{H}-\mathrm{NMR},{ }^{13} \mathrm{C}-\mathrm{NMR}$ spectra were analyzed that the obtained results for vibrational spectra and amount of chemical shift correspond significantly with theoretical methods. Some structural parameters such as bonds length, bonds angle and dihedral angle were studied using theoretical and experimental methods. The parameters such as thermodynamical parameters, dipole moment, HOMO and LUMO energetic values, electrophilicity $(\omega)$, chemical potential $(\mu)$, chemical hardness $(\eta)$ and max amount of electronic charge transfer $\left(\Delta \mathrm{N}_{\max }\right)$ are calculated for this compound in conclusion. The proposed methods were successfully applied to the determination of vibrational spectra, chemical shift amounts and structural parameters.

Keywords: Triazene, Crystal structure, Vibrational frequency, NMR.

\section{Introduction}

Triazenes are a group of compounds with diazo amino functional group and they have high stability to photo, thermo and acids [1-7]. They commonly adopt a trans configuration in the ground state [8]. Triazene compounds contain intramolecular charge-transfer chromophores and, therefore, the presence of electron donating and -withdrawing moieties will have appreciable effect on their UV-vis absorption bands [9-11]. Triazene compounds have been used for the preparation of several sensors for determination of heavy metals $[12,13]$, and also used in solidphase extraction $[14,15]$. They have been studied for their anorectic activity and potency against specific tumor cell lines [16-20], as well as they have been applied as protecting groups in natural product synthesis $[21,22]$ or used to form heterocycles [23, 24]. Various compounds have been prepared from these compounds, because of linkage ability of them to carbonic nano tubes that have important abilities especially in man's body metabolism [25]. A kind of these compounds applied in agronomy chemistry for insecticides and weeds synthesis [26, 27]. However, they have been used in pigments synthesis [27]. Recently, these compounds have been used as ligand to complex synthesis because they have many applications and abilities [11, 28-33]. In some of the triazene complexes variance in molecular structure and present creation possibility of attractive molecular interactions, causes to sit these compounds in super molecules family. The super molecules can use from covalent slender and reversible interaction such as Van der Waals power or hydrogen bond for molecules collection which causes to engender the new properties catalytic activity, new magnetic characterization and response to photo and the structure is applied in many new tendencies [34-36]. This inorganic compounds series can possess special properties and high application, [1-(4-acetylphenyl)3-(2-methylphenyl)] triazene (AMT) can be synthesized by many studies and consideration as

*Corresponding author e-mail: reza.soleymani@hotmail.com

Tel: +98 2633350468- Mob: +989123782899

DOI: 10.21608/ejchem.2018.2176.1173

C2017 National Information and Documentation Center (NIDOC) 
a new type of triazene compound. Its properties were performed some spectroscopic and thermodynamics studies for further consideration. Thus, FT-IR, FT-Raman, ${ }^{1} \mathrm{H}-\mathrm{NMR},{ }^{13} \mathrm{C}-\mathrm{NMR}$ and X-ray single crystal diffraction were studied. Then, this structure in levels HF and DFT were calculated theatrically and the theoretical results of IR vibrational spectra were analyzed Potential Energy Distributions (PEDs) computation and the obtained was compared with experimental results. However, thermodynamic parameters and electrophilicity value, chemical hardness, chemical potential and max amount of electronic charge transfer were calculated via the HOMO and LUMO energetic values.

The electrophilicity index, which measures the stabilization in energy when the system acquires an additional electronic charge, $\Delta \mathrm{N}$ from the environment and is presented in terms of the electronic chemical potential, $\mu$ (the negative of electronegativity, $\chi$ ) and the chemical hardness, $\eta$. Both quantities may be approximated in terms of the energies of frontier molecular orbitals $\left(\varepsilon_{\mathrm{HOMO}}\right.$ and $\left.\varepsilon_{\text {LUMO }}\right)$ as $\mu=\left(\varepsilon_{\mathrm{H}}+\varepsilon_{\mathrm{L}}\right) / 2$ and $\eta=\varepsilon_{\mathrm{L}}-\varepsilon_{\mathrm{H}}$. The Electrophilicity can also be approximated in terms of the ionization potential (I) and electron affinity (A) [37]. High values of $\mu$ and low values of $\eta$, characterize a good electrophone species. The maximum amount of electronic charge $\Delta \mathrm{N}_{\max }$, that the electrophone system may accept $[37,38]$. While the quantity of $\omega$ describes the propensity of the system to acquire additional electronic charge from the environment, the quantity of $\Delta \mathrm{N}_{\max }$ describes the charge capacity of molecule [37].

\section{Experimental}

\section{General method}

All materials were obtained from SigmaAldrich and were used without further purification. The Perkin Elmer RXI spectrometer was used to obtain IR spectra and using $\mathrm{KBr}$ disks in the frequency range of 4000-400 $\mathrm{cm}^{-1}$. The Almega Thermo Nicolet Dispersive Raman spectrometer was used to obtain Raman spectra in the frequency range of $4200-100 \mathrm{~cm}^{-1}$. Elemental analysis was carried out using a Perkin-Elmer 2400(II) $\mathrm{CHNS} / \mathrm{O}$ analyzer. Melting points were measured on a Barnstead Electrothermal 9200 apparatus. The solution absorbencies were monitored using Perkin-Elmer Lambda 25 spectrophotometer, using two matched $10 \mathrm{~mm}$ quartz cells. ${ }^{1} \mathrm{H}$ NMR and ${ }^{13} \mathrm{C}$ NMR spectra were recorded on Bruker Avance $300 \mathrm{MHz}$ spectrometer in deuterated dimethylsulfoxide (DMSO- $\left.\mathrm{d}_{6}\right)$ solvent, and all chemical shifts were reported in $\delta$ unit downfield from $\mathrm{Me}_{4} \mathrm{Si}$. Crystallographic measurements were recorded using graphite monochromated Mo $\mathrm{K}_{\alpha}$ radiation $(\lambda=0.71073 \AA)$. The structure has been solved by direct methods and refined by full-matrix least-squares techniques on F2 using SHELXTL [39]. The molecular structure plots were obtained using Platon [40] and mercury [41]. The weighted R-factor wR and goodness of fit $\mathrm{S}$ and conventional $\mathrm{R}$-factors $\mathrm{R}$ are based on F2 and $\mathrm{F}$ respectively [41-44].

\section{Synthesis}

The synthetic route is shown in Scheme 1. A $1000 \mathrm{ml}$ flask was charged with $300 \mathrm{~g}$ of ice and $150 \mathrm{ml}$ of water and cooled to $0^{\circ} \mathrm{C}$ in an ice bath; then, it was added by $3.38 \mathrm{~g}(25 \mathrm{mmol})$ of 4-Aminoacetophenone and $4.70 \mathrm{~g}(50 \mathrm{mmol})$ of hydrochloric acid $\left(\mathrm{d}=1.19 \mathrm{~g} \mathrm{ml}^{-1}\right)$, a solution of $\mathrm{NaNO}_{2}$ containing $1.80 \mathrm{~g}(25 \mathrm{mmol})$ in $25 \mathrm{ml}$ of water was added in 20 min under electromagnetic stirring solution. After further stirring for $15 \mathrm{~min}$, the solution containing $2.7 \mathrm{ml}(25 \mathrm{mmol})$ was slowly added to resulting solution. The mixture was maintained at $\mathrm{pH}$ 7-8 by adding appropriate amount of aqueous sodium acetate. The mixture was stirred at room temperature for $1.5 \mathrm{~h}$. The yellow product (yield 95\%) was filtered off, washed with water and dried in vacuum. The solid was dissolved in $30 \mathrm{ml}$ pure acetonitrile (stored in a freezer). Orange plate like crystals, which has a melting point of $148-150{ }^{\circ} \mathrm{C}$, was obtained by slow evaporation of the solvent in a week. Infrared and NMR spectra and CHN analysis, were confirmed the AMT structure; ${ }^{1} \mathrm{H}-\mathrm{NMR}(300$ MHz, DMSO-d $\left.{ }_{6}\right) \delta$ 7.19-7.93 (8H, m, phenyl protons), 12.71(1H, s, NH), 2.42 (3H, s, methyl), $2.51\left(3 \mathrm{H}, \mathrm{s}\right.$, acyl). ${ }^{13} \mathrm{C}\left\{{ }^{1} \mathrm{H}\right\}$ NMR $(300 \mathrm{MHz}$, DMSO-d $)_{6} \delta 17.49,26.35,112.85,113.28,117.16$, $126.64,127.48,130.00,130.28,130.72,130.96$, $133.10,145.88,147.55,196.16$. IR $\left(\mathrm{KBr}, v \mathrm{~cm}^{-}\right.$ $\left.{ }^{1}\right)$ : $3217.86(\mathrm{~N}-\mathrm{H}), 3065.53\left(\mathrm{C}-\mathrm{H}, \mathrm{sp}^{2}\right), 1432.52-$ $1596.66(\mathrm{C}=\mathrm{C}), 2919.01,2985.36$ (methyl), $1169.59(\mathrm{~N}-\mathrm{N}), 1659.42(\mathrm{C}=\mathrm{O})$. Elemental Anal. Calc. for $\mathrm{C}_{15} \mathrm{H}_{15} \mathrm{~N}_{3} \mathrm{O}\left(253.3 \mathrm{~g} \mathrm{~mol}^{-1}\right)$ : C, 71.13; $\mathrm{H}, 5.97$; N, 16.59. Found: C, 71.11; H, 5.90; N, $16.62 \%$, CCDC No is 1430754 .

\section{Computational details}

The molecular structure of AMT in grand state is designed preparatory and initial improvement was done on the structure with density function theory and Hartree-Fock methods. Thus, the 


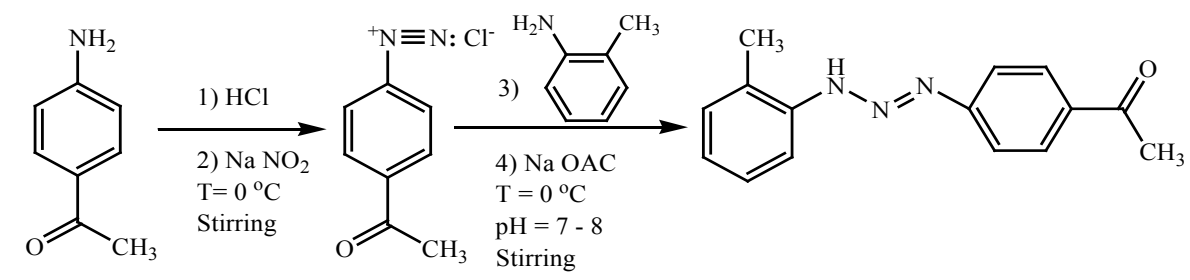

Scheme 1. Synthetic route for the new compound (AMT).

Gaussian 98wprogram package [45], with three different methods HF/B3LYP method with 6-311G (d, p) and B3LYP/6-31G (d) basis sets were used. After the improvement, the vibrational frequency value was calculated and after the calculations, obtained results were extracted and analyzed with Gauss view 03 software [46]. Vibrational frequencies were exploited with their intensity value and for further consonance of the theoretical vibrational frequencies value with the experimental value was used from scaled factor 0.909 for HF/6-311G (d, p), 0.960 for B3LYP/6$31 \mathrm{G}(\mathrm{d})$ method and also 0.967 for B3LYP/6-311G $(d, p)$ method, then started to perform calculations apposite to NMR amounts. For calculation of the NMR amounts GIAO method was used. However, all the chemical shifts were reported based on TMS as a reference [47]. The VEDA 4 software was used for analysis of the obtained spectra and calculation PEDs percent amounts [48]. All the calculations were done with Pentium IV computer, Intel ${ }^{\circledR} \mathrm{CORE}^{\mathrm{TM}}$ i 7 inside $^{\mathrm{TM}} 1.73 \mathrm{GHz}$ job processing with $4 \mathrm{~GB}$ of RAMinto Windows ${ }^{\mathrm{XP}}$ agent.

\section{Result and Discussion}

\section{Description of the crystal structure}

AMT structure is obtained during crystallization process in alcoholic environment. This structure is shown in Fig. 1. This structure has orthorombic system with space group, pbca with 8 unit cell molecule that these parameters are comprising of $\mathrm{a}=8.0665 \AA, \mathrm{b}=8.0019 \AA$ and $\mathrm{c}=21.5249 \AA$ (Table 1). In this structure amount of $R$ (int) for reflection was 0.0306 (Fig. 2). The molecular formula of this structure is $\mathrm{C}_{15} \mathrm{H}_{15} \mathrm{~N}_{3} \mathrm{O}$ and its molecular weight is 253.3. The obtained amounts for some bonds length as N11-C5 $=1.422$ $\AA$, N14-C18=1.391 Å demonstrate approximation the results with the obtained amounts for similar molecules like the DMPF that for $\mathrm{C}-\mathrm{N}$ bond has $1.4130 \AA, 1.2840 \AA, 1.3479 \AA$ amounts [49] and in N,N-bis(2,6-dimethylphenyl)-Noxidoformamidinium compound $\mathrm{C}-\mathrm{N}$ bond length amount is $1.322 \AA[50]$ also in Benzamideoxime structure amount of $\mathrm{C}-\mathrm{N}$ bend is $1.350 \AA$ [51]. N11-N12 bond length is $1.262 \AA$ that has double state. In N14-N12 the bond length is $1.332 \AA$ which is simple form. However, for N11-N12$\mathrm{N} 14$ presents an angle approximately $113.2\left(^{\circ}\right)$ and also there are N12 $-\mathrm{N} 11-\mathrm{C} 5=112.1$, N12 $\mathrm{N} 14-\mathrm{C} 18=119.3\left(^{\circ}\right)$. The most important dihedral angles present in C5-N11-N12-N14=179.9 and C18-N14-N12-N11=179.0 $\left({ }^{\circ}\right)$ that are similar to the results of bonding angles in DMPF and Benzamideoxim structures $[49,51]$. The AMT structure is able to produce polymer with eight cell unit that is done with very strong hydrogen bond production (Fig 2).

Figure 1 shows the AMT optimal structure with atoms number. This structure recovered by B3LYP method 6-31G (d) and 6-311G (d, p) basis sets, HF method and 6-311G (d, p) basis set. The results were reported in Table 2 . The obtained results for the bonds length, bonds angle and also the dihedral angle are similar to experimental results. For example, C5-C9-C13, C26-C29O30, C2-C5-N11 bonding angle use B3LYP/6$311 \mathrm{G}(\mathrm{d}, \mathrm{p})$ method respectively is $121.3\left(^{\circ}\right), 120.8$ $\left(^{\circ}\right)$ and $123.9\left(^{\circ}\right)$. That completely consonant with structure X-ray results that obtained respectively $121.2\left(^{\circ}\right), 120.4\left(^{\circ}\right)$ and $122.4\left(^{\circ}\right)$, of course these results completely consonant with the results of similar compounds as DMFP and N, N-bis(2,6dimethylphenyl)-N-oxidoformamidinium $[49,50]$. The bonds length comparison also demonstrates this order. However, the bond length amount for Carbon-Oxygen bond was obtained $1.212 \AA$ by use of experimental method, 1.191 $\AA$ by use of HF method and $1.217 \AA$ by use of DFT method. The obtained results show CarbonCarbon bond length in Carbonyl group is a little further into rings $\mathrm{C}-\mathrm{C}$ bond length. Attention to the experimental results, HF and DFT C26-C29 is respectively $1.482 \AA, 1.495 \AA$ and $1.493 \AA$, and for $\mathrm{C} 29-\mathrm{C} 31$ is $1.486 \AA, 1.515 \AA$ and $1.520 \AA$. The considered results of ring bonds length are 


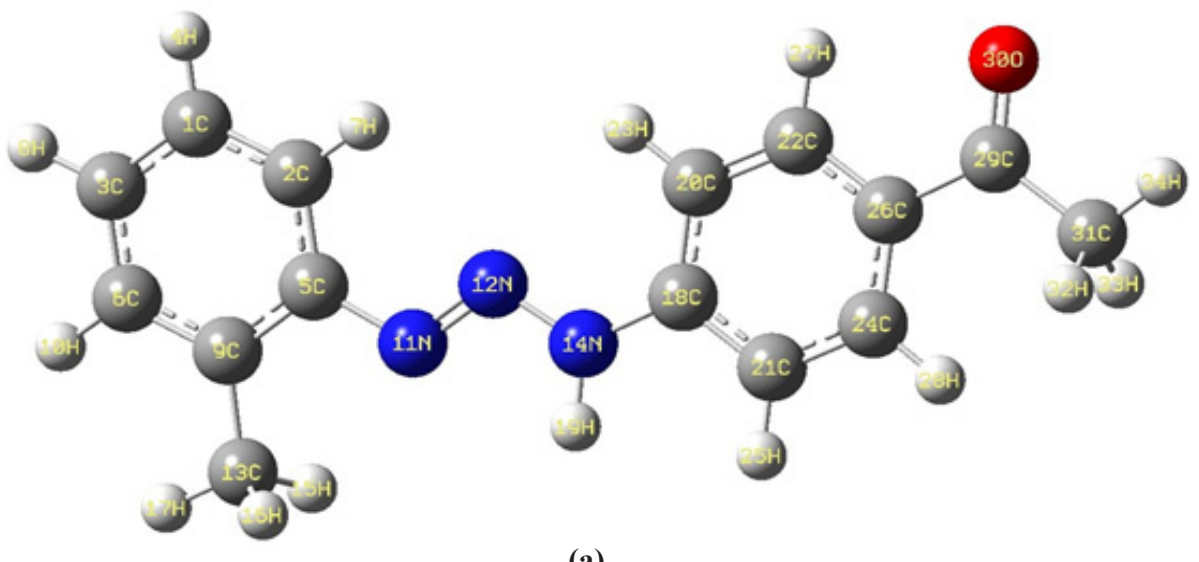

(a)

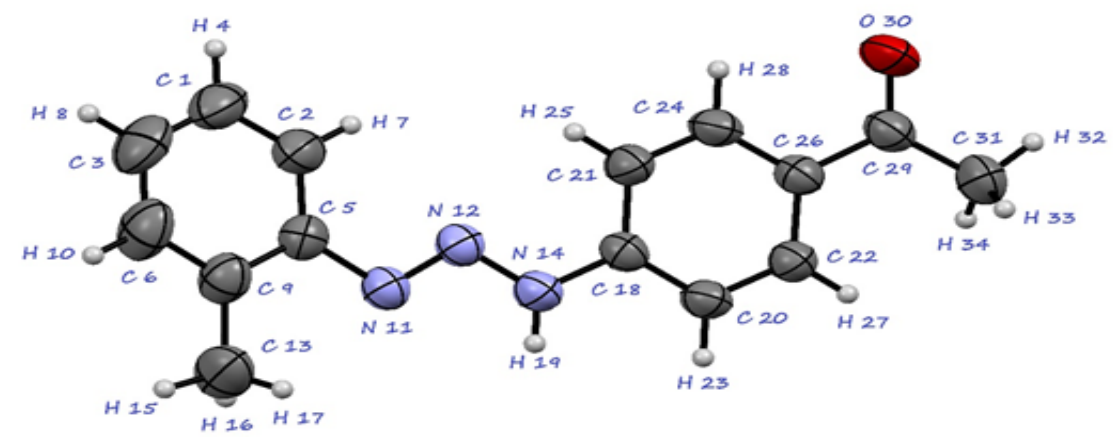

(b)

Fig. 1. (a) Serial number of atom and optimized structure of AMT structure performed byB3LYP/6-311G (d, p) method, (b) The molecular structure of the title compound, displacement ellipsoids are drawn at $50 \%$ probability level.

also under effect of mesomery and resonance and adopt closely to each other amounts. The difference of dihedral angles may be ascribed to the intermolecular forces such as Van der Waals interactions and crystal packing forces in the crystal. All of the theoretical calculations were done in gas phase while the experimental calculations are computed in solid phase. But many of the obtained results via the theoretical calculations were close to the experimentally obtained amounts.

\section{Vibrational assignments}

The AMT molecule consists of 34 atoms, so it has 96 normal vibrational modes. The observed vibrational assignments and analysis of AMT were discussed in terms of fundamental bands. Table 3 lists the wave numbers of bands observed in FT-IR and FT-Raman spectra (Fig 3) of AMT. The scaled theoretical frequencies and infrared intensities calculated by HF/DFT methods of the AMT were also shown in Table 3. Some bands predicted in FT-IR spectra were not observed in the experimental spectrum of AMT molecule (Fig 4). An overall scaling factor has been applied to the calculated frequencies for these levels. The scaling factors are $0.909,0.960$ and 0.967 for HF/6-31G (d, p), B3LYP/6-31G (d) and B3LYP/6$311 \mathrm{G}(\mathrm{d}, \mathrm{p})$ respectively. The relativity between calculation and experiments results were studied and the linear function formula was obtained; $\mathrm{Y}=$ $0.969 \mathrm{X}+15.38$ for $\mathrm{HF} / 6-311 \mathrm{G}(\mathrm{d}, \mathrm{p})$; where $\mathrm{R}^{2}$ is $0.996, \mathrm{Y}=0.946 \mathrm{X}+39.96$ for $\mathrm{B} 3 \mathrm{LYP} / 6-31 \mathrm{G}$ (d); where $R^{2}$ is $0.971, Y=0.946 \mathrm{X}+39.96$ for B3LYP/6-31G $(\mathrm{d})$; where $\mathrm{R}^{2}$ is 0.971 , and $\mathrm{Y}=$ $0.963 \mathrm{X}+35.27$ for B3LYP/6-311G (d, p); where $\mathrm{R}^{2}$ is 0.998 (Fig 5).

\section{C-H vibrations}

The $\mathrm{C}-\mathrm{H}$ vibration type is ranged associated 
to molecule structure. Usually $\mathrm{C}-\mathrm{H}$ stretching vibration in hetro aromatic compounds is observed in frequency range between 2850$3200 \mathrm{~cm}^{-1}$. In $\mathrm{N}, \mathrm{N}$-di(p-thiazole)formamidine structure this type of vibration was shown in region 3112, 3113, 3071 and $2978 \mathrm{~cm}^{-1}$, and in 2-chloro-N-(diethylcarbamothioyl) benzamide, structure, $\mathrm{C}-\mathrm{H}$ stretching was observed in region $2872 \mathrm{~cm}^{-1}$ to $3091 \mathrm{~cm}^{-1}$ [52], in the AMT structure, three important vibrations 2741, 2919 and 2985 $\mathrm{cm}^{-1}$, duration FT-IR method and four important vibration 2774, 3020, 3060 and $3123 \mathrm{~cm}^{-1}$ by FT-Raman method were observed. The obtained results were confirmed use of B3LYP and $\mathrm{HF}$ theoretical methods. However, for $\mathrm{C}-\mathrm{H}$ bending vibrations, there were two in-plane and out-of plane vibrational states. A vibration in range of $1000 \mathrm{~cm}^{-1}$ to $1300 \mathrm{~cm}^{-1}$ was attended for aromatic in-plane bending vibration. The most important of these bending vibrations were observed use B3LYP/6-311G (d, p) method 1141, 1151, 1162 and $1200 \mathrm{~cm}^{-1}$. Those results were confirmed by PEDs analyses which were close to the AMT results that its in-plane vibrations were 1277 , $1253,1247,1139$ and $1136 \mathrm{~cm}^{-1}$. Intensity of these vibrations was approximately fine and strong. The vibrations 1033, 1030, 1012 and $974 \mathrm{~cm}^{-1}$ were seen use of B3LYP/6-311G (d, p) method for C-H out-of plane bending vibration. The $\mathrm{C}-\mathrm{H}$ bending vibrations 1110, 1078, 1045 and $1021 \mathrm{~cm}^{-1}, \mathrm{C}-\mathrm{H}$ also was recognizable in experimental results that have the week intensity to in-plane vibrations.

\section{$\mathrm{C}=\mathrm{O}$ and $\mathrm{CH}_{3}$ vibrations}

The $\mathrm{C}-\mathrm{H}$ bending vibrations were observed on two forms. For aromatic ring $\mathrm{C}-\mathrm{H}$ that have $\mathrm{SP}^{2}$ hybridation was seen 3065 and $3040 \mathrm{~cm}^{-1}$ use FT-IR method, 3123, 3060 and $3020 \mathrm{~cm}^{-1}$ in FTRaman method. The obtained theoretical results and PEDs analyses have demonstrated this. But the bending $\mathrm{C}-\mathrm{H}$ for $\mathrm{CH}_{3}$ was seen in region sub 3000 that $2919 \mathrm{~cm}^{-1}$ and $2985 \mathrm{~cm}^{-1}$ was seen using the FT-IR and $2774 \mathrm{~cm}^{-1}$ in FT-Raman, because the $\mathrm{CH}_{3}$ hybridation is $\mathrm{SP}^{3}$ meanwhile for $\mathrm{C}=\mathrm{O}$ was seen a vibration of $1659 \mathrm{~cm}^{-1}$ in FT-IR and 1754 $\mathrm{cm}^{-1}$ in FT-Raman, $1780 \mathrm{~cm}^{-1}$ in HF method, 1699 $\mathrm{cm}^{-1}$ in B3LYP/6-31G (d) method and $1693 \mathrm{~cm}^{-1}$ in B3LYP/6-311G (d, p) method, that its intensity was very much in FT-IR spectrum. In 2-chloro$\mathrm{N}$-(diethylcarbamothioyl) benzamide structure was observed use of the FT-IR method vibration amplitude in region $1655 \mathrm{~cm}^{-1}$ and use of the B3LYP the vibration amplitude in region 1723 $\mathrm{cm}^{-1}$ that were very close with the AMT structure result. But the bending vibrations for $\mathrm{C}-\mathrm{O}$ was seen also in 588, 559, $496 \mathrm{~cm}^{-1}$ in the FT-IR spectrum. Those theoretical vibrations confirm this topic use the B3LYP/6-311G (d, p) method.

\section{C-C vibrations}

Carbon-Carbon vibration will different in the various parts of structure. The $\mathrm{C}-\mathrm{C}$ stretching vibrations are changed in region 1430 to 1625 $\mathrm{cm}^{-1}$. In general, the bands are of variable intensity and are observed at 1625-1590 $\mathrm{cm}^{-1}$, $1590-1575 \mathrm{~cm}^{-1}, 1540-1470 \mathrm{~cm}^{-1}, 1465-1430$ $\mathrm{cm}^{-1}$ and $1380-1280 \mathrm{~cm}^{-1}$ from the wave number ranges given by Varsanyi [53] for the five bands in the region. The $\mathrm{C}=\mathrm{C}$ stretching vibration in the FT-IR spectrum was observed in region 1521, 1586 and $1596 \mathrm{~cm}^{-1}$, in the FT-Raman spectrum was observed in region $1600 \mathrm{~cm}^{-1}$. These results were completely consonance with the theoretical results in the B3LYP/6-311G $(\mathrm{d}, \mathrm{p})$ method this vibration was observed in region $1560,1566,1587$ and $1589 \mathrm{~cm}^{-1}$. The obtained results were similar to the obtained vibrations amplitude for $\mathrm{C}=\mathrm{C}$ in DMFP and $\mathrm{N}, \mathrm{N}$-di(p-thiazole)formamidine $[49$, 50]. But $\mathrm{C}-\mathrm{C}-\mathrm{C}$ bending vibration was observable in the FT-IR spectrum in region 496, 559, 623, 646 and $696 \mathrm{~cm}^{-1}$ that was observed use the theoretical calculations in the B3LYP/6$311 \mathrm{G}(\mathrm{d}, \mathrm{p})$ level of theory, the bending vibrations in region 525, 551, 599, 619, 639 and $703 \mathrm{~cm}^{-1}$. In DMFP structure the $\mathrm{C}-\mathrm{C}-\mathrm{C}$ vibrations were seen in region $800,618,573$ and $483 \mathrm{~cm}^{-1}$ that are close and similar to obtained results. For the AMT structure [49], of course, it is mention that the intensity of these peaks was at middle region and approximately week. In the Benzamideoxime structure this vibration was seen use experimental methods in region $600 \mathrm{~cm}^{-1}$ and $625 \mathrm{~cm}^{-1}$ [51]. But the PEDs shows which of vibrations maybe not seen individual at frequency, but closing of the theoretical and the experimental was respectively and detectable.

\section{$N$-H vibrations}

In AMT is presented one hydrogen linked to nitrogen group. In all hetrocyclic compounds $\mathrm{N}-\mathrm{H}$ stretching vibration is recognizable in region $3000 \mathrm{~cm}^{-1}$ to $3500 \mathrm{~cm}^{-1}$. Tsuboi [54] reported the $\mathrm{N}-\mathrm{H}$ stretching frequency at $3481 \mathrm{~cm}^{-1}$ in aniline. However, in DMFP structure the $\mathrm{N}-\mathrm{H}$ stretching vibration obtained experimentally in region 3301 $\mathrm{cm}^{-1}$ and by B3LYP/6-311+G (d, p) method in region $3448 \mathrm{~cm}^{-1}$ [49]. In $\mathrm{N}, \mathrm{N}-\mathrm{di}(\mathrm{p}-$ thiazole) 

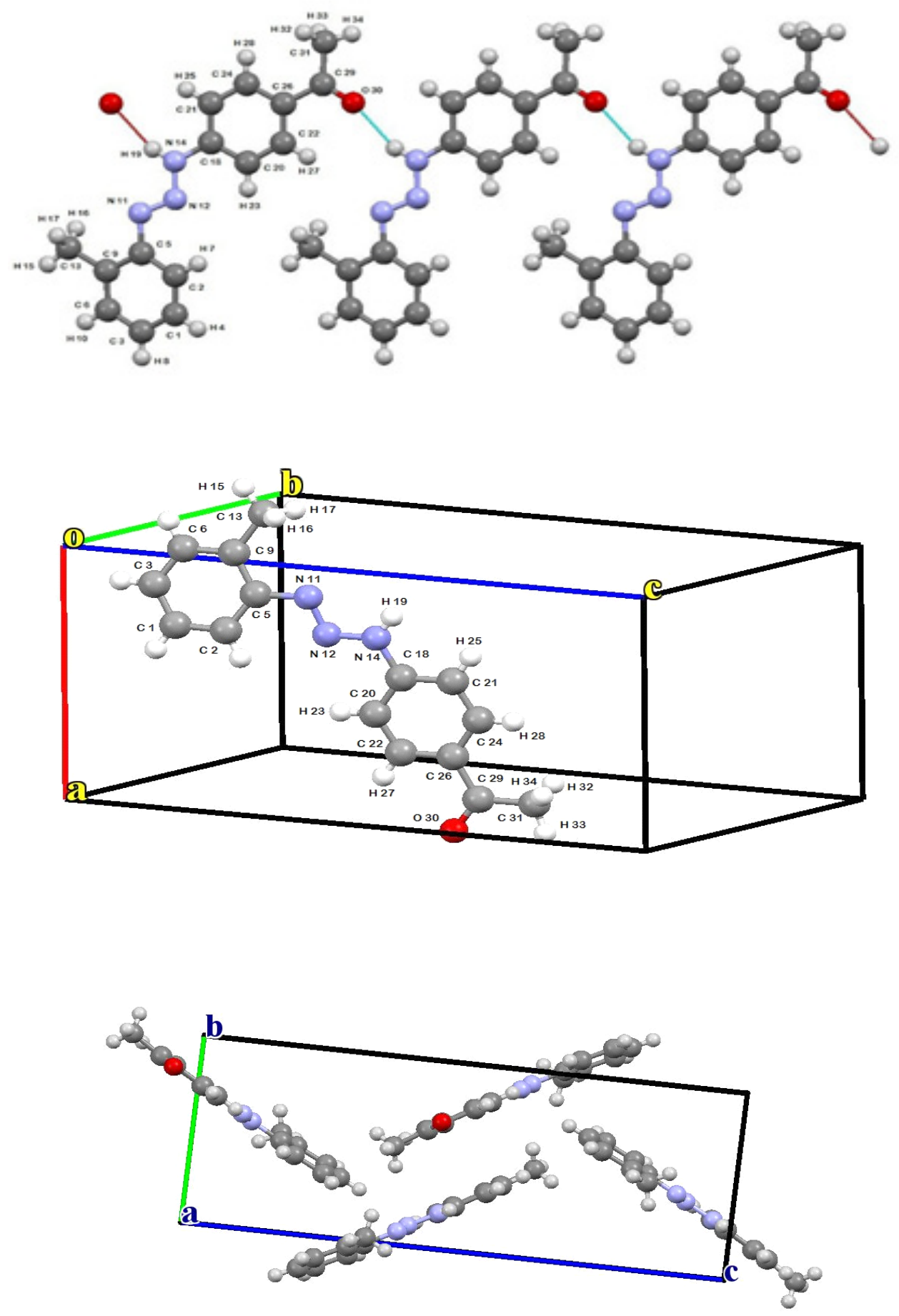

Fig. 2. A view of the crystal packing down the $\alpha$-axis for the title compound. Hydrogen bonds are shown as dashed lines. 


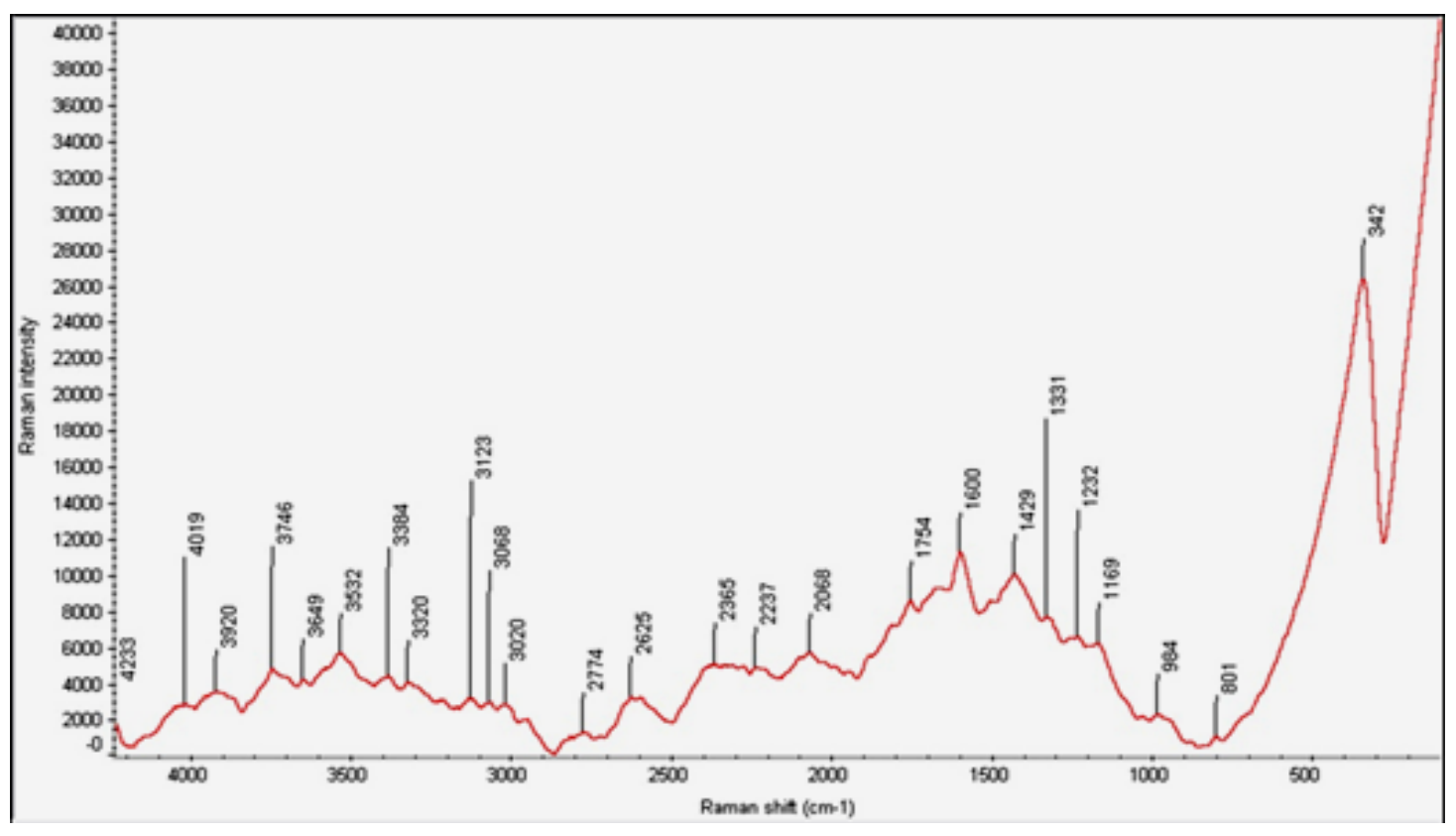

Fig. 3. FT-Raman spectrum of AMT.

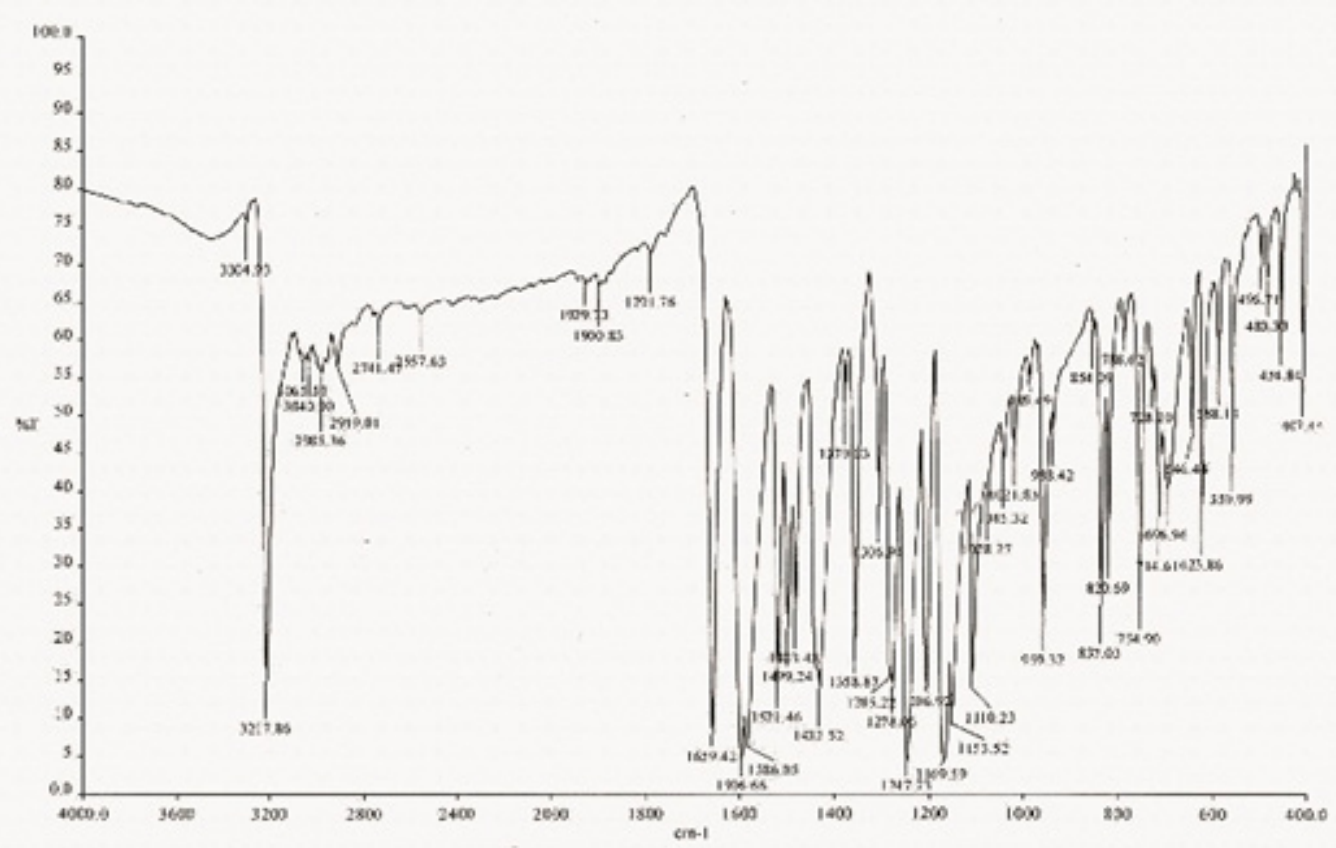

Fig. 4. Show FT-IR spectrum obtained experimental method for the title compound. 


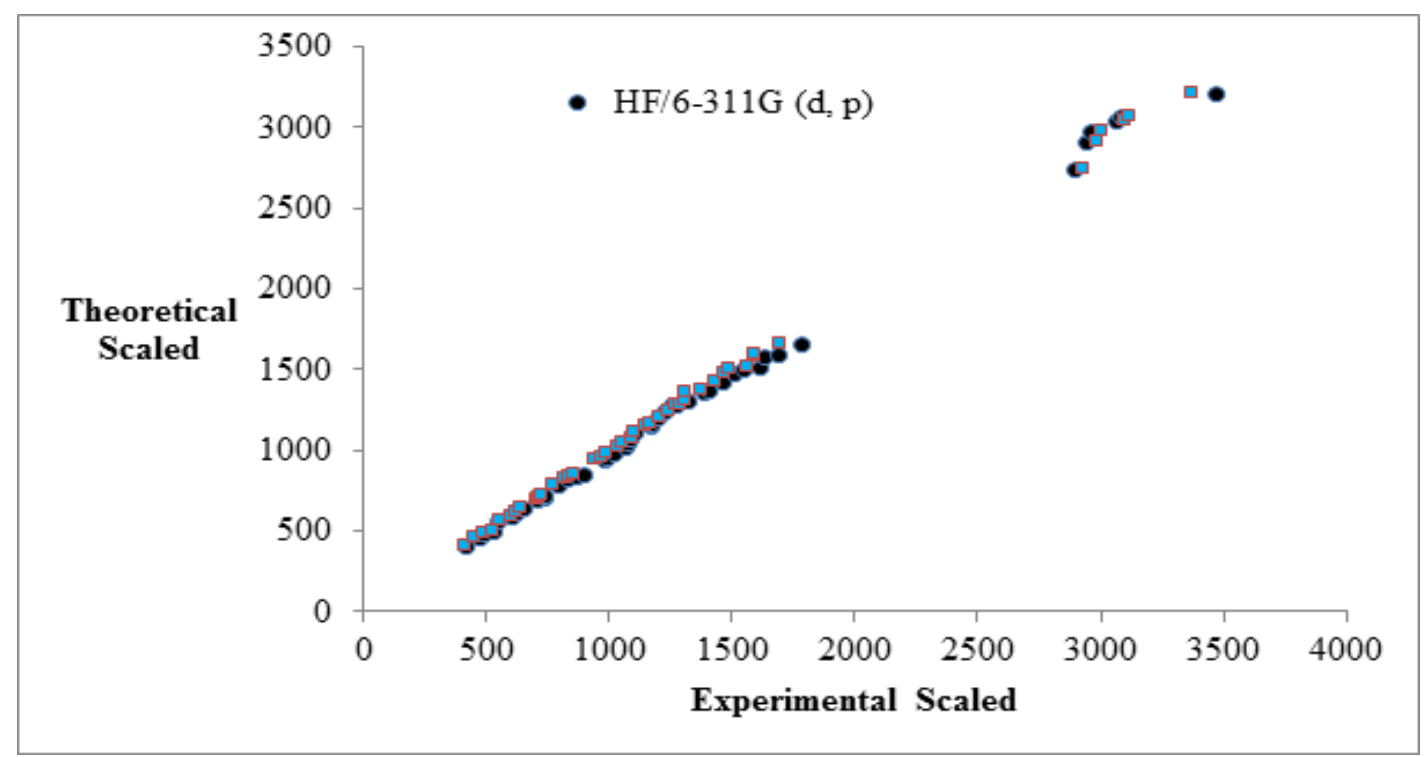

Fig. 5. Correlation between experimental and theoretical frequencies [HF/6-311G (d, p) and B3LYP/6-311G (d, p) methods].

formamidine structure the $\mathrm{N}-\mathrm{H}$ stretching vibration in region $3258 \mathrm{~cm}^{-1}$ was observed [50]. The FT-IR spectrum results showed the value of the $\mathrm{N}-\mathrm{H}$ stretching vibration in AMT with very strong intensity in region $3217 \mathrm{~cm}^{-1}$ and the FTRaman also shows how this vibration with lighter intensity in region $3532 \mathrm{~cm}^{-1}$. However, the results of $\mathrm{HF} / 6-311 \mathrm{G}(\mathrm{d}, \mathrm{p}), \mathrm{B} 3 \mathrm{LYP} / 6-31 \mathrm{G}(\mathrm{d})$ and B3LYP/6-311G $(d, p)$ methods showed the $\mathrm{N}-\mathrm{H}$ vibration respectively in frequencies 3463 , 3344 and $3369 \mathrm{~cm}^{-1}$, for the in-plane bending vibration was observed in regions 1231, 1456 and $1507 \mathrm{~cm}^{-1}$ use B3LYP/6-311G (d, p) method. For similar compounds such as $\mathrm{N}, \mathrm{N}$-di( $p$-thiazole) formamidine, these vibrations were obtained in region 1278,1410 and $1545 \mathrm{~cm}^{-1}$ and the out-of plane the $\mathrm{N}-\mathrm{H}$ bending vibration was observed in region $603 \mathrm{~cm}^{-1}$. This vibration was obtained in region $565 \mathrm{~cm}^{-1}$ for the structure and $\mathrm{N}, \mathrm{N}-\mathrm{di}(\mathrm{p}-$ thiazole) formamidine [50]. In Benzamideoxime structure, the bending $\mathrm{N}-\mathrm{H}$ vibration same amplitude was observed in region $3233 \mathrm{~cm}^{-1}$ and $3262 \mathrm{~cm}^{-1}$ that correspond with the obtained results for AMT [51].

\section{$C-N$ vibrations}

In aromatic amines $\mathrm{C}-\mathrm{N}$ range is variable in region $1200 \mathrm{~cm}^{-1}$ to $1330 \mathrm{~cm}^{-1}$. In compounds such as benzoxazolethe $\mathrm{C}-\mathrm{N}$ stretching vibration obtained as $1332 \mathrm{~cm}^{-1}$ (FT-IR), $1315 \mathrm{~cm}^{-1}$ (FTRaman) and $1315 \mathrm{~cm}^{-1}$ (HF) [55]. However, in the DMFP structure the vibration value was observed by B3LYP method in $1253 \mathrm{~cm}^{-1}$ and by FT-Raman method in region $1285 \mathrm{~cm}^{-1}$ [49]. In 2-chloro-N(diethylcarbamothioyl) benzamide structure the $\mathrm{C}-\mathrm{N}$ vibration amplitude was obtained in region $1221 \mathrm{~cm}^{-1}$ and $1203 \mathrm{~cm}^{-1}$ that are related to Carbon linked to $\mathrm{N}-\mathrm{H}$ [52]. For BDMF structure, there are two $\mathrm{C}-\mathrm{N}$ stretching vibration region. The first vibration is related to Carbon linked to Nitrogen with double bond, which its vibrational amplitude is variable between $1260 \mathrm{~cm}^{-1}$ to $1330 \mathrm{~cm}^{-1}$ and the second vibration is correlated to Carbon linked to $\mathrm{N}-\mathrm{H}$ group, that the vibrational amplitude is placed in higher frequency that is demonstrated use PEDs analysis by FT-IR spectrum consideration. The $\mathrm{C}-\mathrm{N}$ stretching vibration was observed in 1206 $\mathrm{cm}^{-1}$. That it possesses strong peak intensity. The FT-Raman spectrum considers shows the $\mathrm{C}-\mathrm{N}$ vibration in $1232 \mathrm{~cm}^{-1}$. The theoretical studies in level B3LYP/6-311 G (d, p) demonstrate the experimental results and show the $\mathrm{C}-\mathrm{N}$ vibration amplitude related to Carbon linked to nitrogen in regions $1200 \mathrm{~cm}^{-1}$ and $1231 \mathrm{~cm}^{-1}$, related to Carbon linked to $\mathrm{N}-\mathrm{H}$ in $1537 \mathrm{~cm}^{-1}$. Some bending vibrations of $\mathrm{C}-\mathrm{N}$ are able to observe with approximately middle intensity using FT-IR method in $407 \mathrm{~cm}^{-1}$ and $588 \mathrm{~cm}^{-1}$ that correspond completely with theoretical results in B3LYP/6$311 \mathrm{G}(\mathrm{d}, \mathrm{p})$ level that shows these vibrations in $408 \mathrm{~cm}^{-1}$ and $599 \mathrm{~cm}^{-1}$.

$N=N$ and $N-N$ vibrations

In AMT structure $\mathrm{N}-\mathrm{N}$ bond presents in 
TABLE 1. Crystal data and structure refinement.

\begin{tabular}{|c|c|}
\hline Empirical formula & $\mathrm{C}_{15} \mathrm{H}_{15} \mathrm{~N}_{3} \mathrm{O}$ \\
\hline Formula weight & 253.3 \\
\hline Temperature (K) & $296(2)$ \\
\hline Wavelength (Á) & 0.71073 \\
\hline Crystal system, space group & Orthorhombic, $\mathrm{Pbca}$ \\
\hline \multicolumn{2}{|l|}{ Unit cell dimensions } \\
\hline$a(\AA), \alpha\left(^{\circ}\right)$ & $8.0665(2), 90.0000$ \\
\hline$b(\AA)), \beta\left({ }^{\circ}\right)$ & $8.0019(2), 96.7170(10)$ \\
\hline$c(\AA)), \gamma\left({ }^{\circ}\right)$ & $21.5249(5), 90.0000$ \\
\hline Volume $\left(\AA^{3}\right)$ & $1379.84(6)$ \\
\hline$Z$, Calculated density $\left(\mathrm{Mg} / \mathrm{m}^{3}\right)$ & $4,1.219$ \\
\hline Absorption coefficient $\left(\mathrm{mm}^{-1}\right)$ & 0.079 \\
\hline$F(000)$ & 536 \\
\hline Crystal size (mm) & $0.2 \times 0.4 \times 0.3$ \\
\hline Theta range for data collection (deg) & 2.61 to 27.00 \\
\hline Max/min. indices $h, k, l$ & $-10 / 10,-10 / 10,-27 / 27$ \\
\hline Reflections collected & 47440 \\
\hline Independent reflections $[R$ (int)] & $3009[0.0306]$ \\
\hline Completeness to theta $=27.00(\%)$ & 99.80 \\
\hline Refinement method & Full-matrix least-squares on $\mathrm{F}^{2}$ \\
\hline Data / restraints / parameters & $3009 / 0 / 181$ \\
\hline Goodness-of-fit on $\mathrm{F}^{2}$ & 1.057 \\
\hline Final $R$ indices [I $>2 \operatorname{sigma~(I)]~}$ & $R_{1}=0.0431, \omega R_{2}=0.1178$ \\
\hline$R$ indices (all data) & $R_{1}=0.0612, \omega R_{2}=0.1366$ \\
\hline Largest diff. peak and hole (e. $\left.\AA^{-3}\right)$ & 0.187 and -0.161 \\
\hline
\end{tabular}


TABLE 2. Computed and experimental bond distances (A), bond angles $\left({ }^{\circ}\right)$, torsion angles $\left({ }^{\circ}\right)$ for AMT structure.

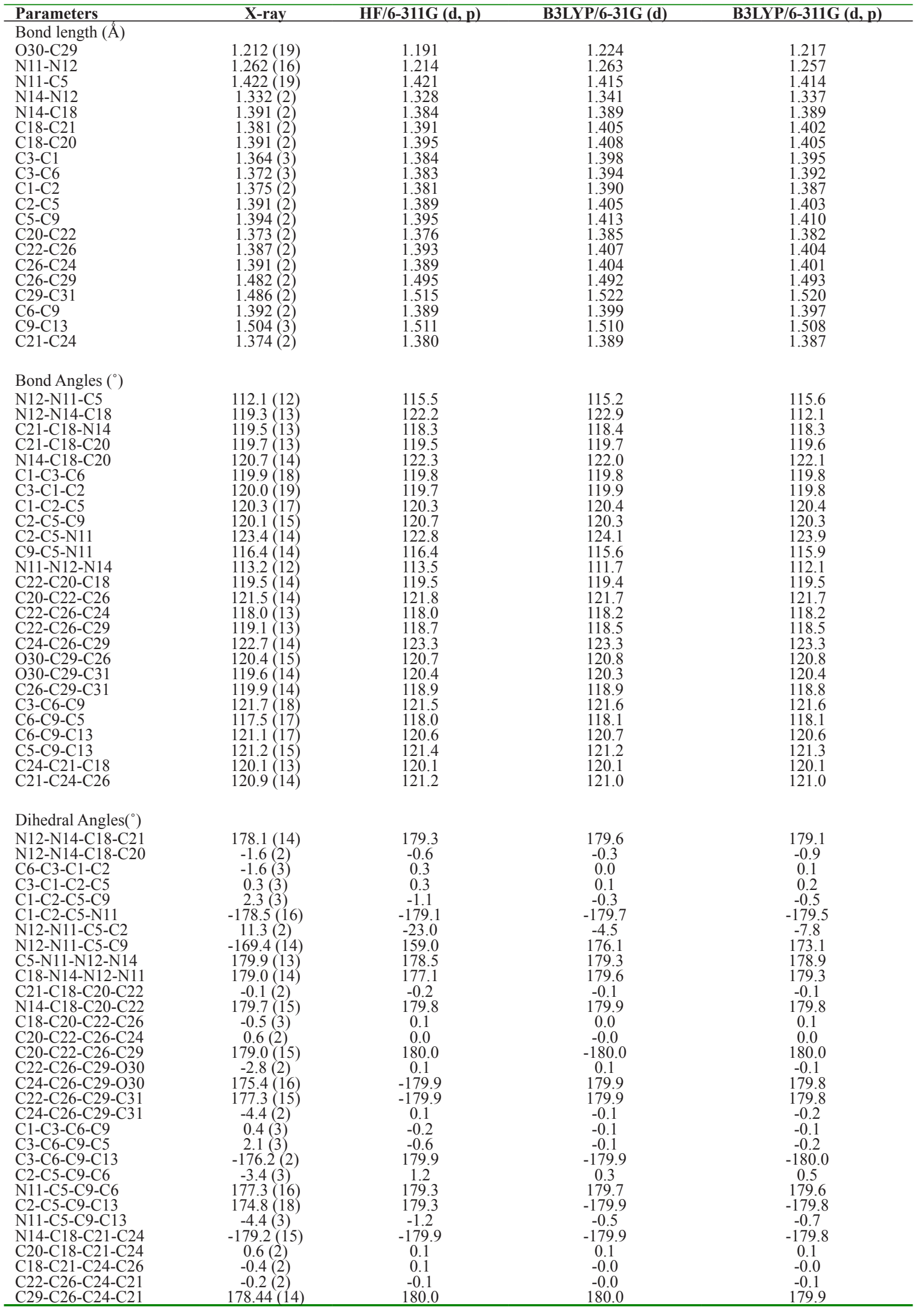

Egypt. J. Chem. 61, No. 2 (2018) 
TABLE 3. Vibrational wavenumbers obtained for AMT structure at B3LYP/6-31G (d), B3LYP/6-311G (d, p) and HF/6-311G (d, p) method [harmonic frequency $\left(\mathrm{cm}^{-1}\right)$, IRint $\left.\left(\mathrm{Kmmol}^{-1}\right)\right]$.

\begin{tabular}{|c|c|c|c|c|c|c|c|c|c|}
\hline \multirow{3}{*}{$\begin{array}{l}\text { Mod } \\
\text { nos. }\end{array}$} & \multicolumn{2}{|c|}{ Experimental $\left(\mathrm{cm}^{-1}\right)$} & \multicolumn{6}{|c|}{ Theoretical wavenumber $\left(\mathrm{cm}^{-1}\right)$} & \multirow{3}{*}{$\operatorname{PED}(\%)^{\mathrm{c}}$} \\
\hline & \multirow{2}{*}{ FT-IR } & \multirow{2}{*}{$\begin{array}{c}\text { FT- } \\
\text { Raman }\end{array}$} & \multicolumn{2}{|c|}{$H F / 6-311 G(d, p)$} & \multicolumn{2}{|c|}{ B3LYP/6-31G (d) } & \multicolumn{2}{|c|}{$\begin{array}{l}\text { B3LYP/6-311G } \\
\quad(d, p)\end{array}$} & \\
\hline & & & Scaled & $\mathbf{I R}_{\text {int }}{ }^{\mathrm{b}}$ & Scaled & $\mathbf{I R}_{\text {int }}{ }^{\mathrm{b}}$ & Scaled & $\mathbf{I R}_{\text {int }} \mathrm{b}^{\mathrm{b}}$ & \\
\hline 1 & & & 15 & 0.56 & 4 & 1.04 & 6 & 0.96 & $11 \Gamma N N N C+70 \Gamma C C N N$ \\
\hline 2 & & & 22 & 2.68 & 26 & 0.90 & 28 & 0.90 & $18 \Gamma N N N C+45 \Gamma N N C C$ \\
\hline 3 & & & 43 & 0.89 & 44 & 0.73 & 44 & 0.73 & $20 \delta \mathrm{CNN}+20 \delta \mathrm{NNN}+30 \delta \mathrm{NNC}+14 \delta \mathrm{NCC}$ \\
\hline 4 & & & 63 & 1.89 & 70 & 1.47 & 69 & 1.69 & $79 \Gamma \mathrm{rccc}$ \\
\hline 5 & & & 79 & 0.18 & 78 & 0.40 & 78 & 0.30 & $\begin{array}{c}17 \Gamma \mathrm{CCCN}+18 \Gamma \mathrm{CCCC}+11 \Gamma \mathrm{CNNN}+ \\
16 \lambda \mathrm{CCCC}\end{array}$ \\
\hline 6 & & & 118 & 2.57 & 108 & 0.07 & 107 & 0.13 & $29 \Gamma \mathrm{NNNC}+28 \Gamma \mathrm{HCCC}+22 \Gamma \mathrm{HCCC}$ \\
\hline 7 & & & 126 & 0.07 & 130 & 0.98 & 130 & 0.45 & $19 \Gamma \mathrm{HCCC}+12 \mathrm{CCCN}+13 \lambda \mathrm{CCCC}$ \\
\hline 8 & & & 138 & 1.07 & 137 & 0.44 & 140 & 0.37 & $10 \delta \mathrm{CNN}+16 \delta \mathrm{CNN}+10 \delta \mathrm{NCC}+12 \delta \mathrm{CCC}$ \\
\hline 9 & & & 158 & 0.01 & 154 & 0.15 & 149 & 0.15 & $34 \Gamma \mathrm{HCCC}+34 \Gamma \mathrm{HCCC}+22 \Gamma \mathrm{HCCC}$ \\
\hline 10 & & & 173 & 0.92 & 178 & 1.90 & 178 & 1.79 & $138 \mathrm{CCC}$ \\
\hline 11 & & & 189 & 3.88 & 182 & 4.31 & 183 & 3.64 & $26 \Gamma N N N C+18 \Gamma N N C C$ \\
\hline 12 & & & 213 & 8.62 & 200 & 5.17 & 201 & 6.38 & $\begin{array}{c}12 \Gamma \mathrm{CCCC}+15 \Gamma \mathrm{CCCC}+14 \Gamma \mathrm{CNNN}+ \\
20 \lambda \mathrm{CCCC}\end{array}$ \\
\hline 13 & & & 239 & 7.48 & 237 & 7.65 & 238 & 7.73 & $10 \delta \mathrm{NCC}+23 \delta \mathrm{CCC}+14 \delta \mathrm{CCC}$ \\
\hline 14 & & & 279 & 0.03 & 275 & 0.07 & 276 & 0.08 & $25 \Gamma \mathrm{CCCC}+26 \lambda \mathrm{CCCC}+12 \lambda \mathrm{NCCC}$ \\
\hline 15 & & & 316 & 9.75 & 314 & 9.34 & 316 & 10.29 & $32 \delta \mathrm{CCC}$ \\
\hline 16 & & $342 \mathrm{vs}$ & 336 & 2.13 & 320 & 0.01 & 323 & 0.02 & $14 \Gamma \mathrm{CCCC}+33 \Gamma \mathrm{CNNN}$ \\
\hline 17 & & & 390 & 28.57 & 386 & 36.44 & 388 & 35.33 & $15 \delta \mathrm{OCC}+12 \delta \mathrm{NNN}$ \\
\hline 18 & & & 412 & 11.41 & 403 & 0.04 & 406 & 0.03 & $10\ulcorner\mathrm{HCCC}+40 \Gamma \mathrm{CCCC}+28 \Gamma \mathrm{\Gamma CCC}$ \\
\hline 19 & $407 \mathrm{~m}$ & & 416 & 0.04 & 405 & 7.61 & 408 & 7.80 & $15 \delta \mathrm{CCN}+12 \delta \mathrm{NCC}+13 \delta \mathrm{CCC}+22 \delta \mathrm{CCC}$ \\
\hline 20 & $457 w$ & & 464 & 8.48 & 450 & 3.34 & 453 & 5.99 & $10 \Gamma \mathrm{HCCC}+22 \Gamma \mathrm{CCCC}+30 \lambda \mathrm{CCCC}$ \\
\hline 21 & & & 469 & 3.07 & 464 & 1.23 & 467 & 1.61 & $13 \delta \mathrm{CCC}+11 \delta \mathrm{CCC}+21 \delta \mathrm{CCC}$ \\
\hline 22 & $483 w$ & & 488 & 15.99 & 484 & 0.33 & 486 & 2.87 & $13\ulcorner\mathrm{CCCC}+10 \lambda \mathrm{OCCC}+41 \lambda \mathrm{NCCC}$ \\
\hline 23 & $496 \mathrm{vw}$ & & 521 & 64.56 & 521 & 0.24 & 525 & 0.25 & $14 v \mathrm{CC}+108 \mathrm{OCC}+118 \mathrm{CCC}+198 \mathrm{CCC}$ \\
\hline 24 & & & 527 & 4.28 & 537 & 0.40 & 542 & 1.30 & 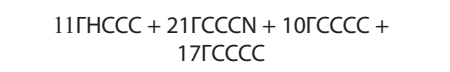 \\
\hline 25 & $559 \mathrm{~m}$ & & 547 & 15.95 & 546 & 10.24 & 551 & 9.21 & $16 \delta \mathrm{OCC}+11 \delta \mathrm{CCC}$ \\
\hline 26 & & & 560 & 5.36 & 574 & 0.71 & 579 & 2.61 & $25 \Gamma \mathrm{HCCC}+34 \lambda \mathrm{OCCC}$ \\
\hline 27 & $588 w$ & & 596 & 34.19 & 594 & 6.32 & 599 & 6.77 & $150 \mathrm{CC}+23 \delta \mathrm{OCC}+10 \delta \mathrm{NNC}$ \\
\hline 28 & & & 603 & 8.60 & 606 & 90.80 & 611 & 79.39 & $88 \Gamma \mathrm{HNNN}$ \\
\hline 29 & $623 \mathrm{~m}$ & & 622 & 30.04 & 614 & 34.37 & 619 & 35.49 & $15 \delta \mathrm{CCC}+14 \delta \mathrm{CCC}+12 \delta \mathrm{CCC}$ \\
\hline 30 & $646 \mathrm{~m}$ & & 644 & 7.81 & 635 & 8.64 & 639 & 8.16 & $14 \delta \mathrm{CCC}+11 \delta \mathrm{CCC}+10 \delta \mathrm{CCC}$ \\
\hline 31 & $696 \mathrm{~m}$ & & 706 & 9.60 & 700 & 16.84 & 703 & 16.71 & $13 v \mathrm{CC}+12 v \mathrm{CC}+18 \delta \mathrm{CCC}$ \\
\hline 32 & $714 \mathrm{~m}$ & & 732 & 0.44 & 707 & 11.42 & 716 & 22.31 & $\begin{array}{c}15 \Gamma \mathrm{HCCC}+15 \Gamma \mathrm{HCCC}+11 \Gamma C C C C+ \\
11 \Gamma C C C C\end{array}$ \\
\hline 33 & $728 \mathrm{~s}$ & & 736 & 16.49 & 709 & 0.15 & 722 & 0.10 & $14 \Gamma \mathrm{rCCCC}+35 \Gamma \mathrm{rCCCC}+14 \Gamma \mathrm{r} C \mathrm{CC}$ \\
\hline 34 & & & 769 & 14.36 & 753 & 28.88 & 760 & 29.60 & $\begin{array}{c}15 \Gamma \mathrm{HCCC}+15 \Gamma \mathrm{HCCC}+16 \Gamma \mathrm{HCCC}+ \\
21 \Gamma C C C C\end{array}$ \\
\hline 35 & $788 \mathrm{vw}$ & & 788 & 48.92 & 769 & 3.76 & 772 & 5.97 & $160 \mathrm{CC}+24 \delta \mathrm{CCC}$ \\
\hline 36 & & & 817 & 2.89 & 791 & 23.03 & 794 & 25.44 & $55 \Gamma \mathrm{HCCC}+23 \Gamma \mathrm{HCCC}$ \\
\hline 37 & $820 \mathrm{~m}$ & $801 \mathrm{vw}$ & 828 & 29.45 & 812 & 0.74 & 816 & 1.18 & $20 \delta \mathrm{CCC}$ \\
\hline 38 & $837 \mathrm{~s}$ & & 861 & 43.45 & 829 & 26.85 & 834 & 31.98 & $55 \Gamma \mathrm{HCCC}+18 \Gamma \mathrm{HCCC}+12 \lambda \mathrm{NCCC}$ \\
\hline 39 & $854 \mathrm{vw}$ & & 890 & 1.78 & 850 & 1.00 & 855 & 1.69 & $21 \Gamma \mathrm{HCCC}+24 \Gamma \mathrm{HCCC}+36 \Gamma \mathrm{HCCC}$ \\
\hline 40 & & & 925 & 6.45 & 911 & 0.01 & 918 & 6.74 & $15 \delta \mathrm{NNN}+10 \delta \mathrm{CCC}$ \\
\hline 41 & & & 943 & 42.18 & 912 & 0.91 & 923 & 0.03 & $24 \Gamma \mathrm{HCCC}+58 \Gamma \mathrm{HCCC}$ \\
\hline 42 & & & 971 & 0.02 & 917 & 1.51 & 924 & 78.21 & $300 \mathrm{CC}+13 \Gamma \mathrm{HCCC}+13 \Gamma \mathrm{HCCC}$ \\
\hline 43 & $938 w$ & & 979 & 2.06 & 927 & 75.35 & 935 & 1.78 & $28 \Gamma \mathrm{HCCC}+32 \Gamma \mathrm{HCCC}+25 \Gamma \mathrm{HCCC}$ \\
\hline 44 & $959 m$ & & 983 & 12.80 & 947 & 0.04 & 964 & 0.13 & $\begin{array}{c}37 \Gamma \mathrm{HCCC}+19 \Gamma \mathrm{HCCC}+19 \Gamma \mathrm{HCCC}+ \\
17 \Gamma C C C C\end{array}$ \\
\hline
\end{tabular}




\section{TABLE 3. Cont.}

\begin{tabular}{|c|c|c|c|c|c|c|c|c|c|}
\hline 45 & & & 996 & 7.71 & 960 & 0.21 & 974 & 3.76 & $\begin{array}{c}100 \mathrm{CC}+10 \delta \mathrm{HCH}+12 \delta \mathrm{CCC}+24 \Gamma \mathrm{HCCC} \\
+20\ulcorner\mathrm{HCCC}\end{array}$ \\
\hline 46 & & & 1010 & 0.24 & 977 & 3.31 & 975 & 0.26 & $23 \Gamma \mathrm{HCCC}+58 \Gamma \mathrm{HCCC}$ \\
\hline 47 & $989 \mathrm{vw}$ & $984 w$ & 1016 & 0.19 & 986 & 1.16 & 989 & 1.03 & $38 \delta \mathrm{CCC}+24 \delta \mathrm{CCC}+17 \delta \mathrm{CCC}$ \\
\hline 48 & & & 1035 & 5.08 & 1013 & 1.75 & 1012 & 1.01 & $\begin{array}{c}13 \Gamma \mathrm{HCCC}+13 \Gamma \mathrm{HCCC}+15 \Gamma \mathrm{HCCC}+ \\
27 \delta \mathrm{HCC}\end{array}$ \\
\hline 49 & & & 1043 & 1.81 & 1033 & 3.31 & 1030 & 2.62 & $\begin{array}{c}10 \delta \mathrm{HCH}+11 \delta \mathrm{HCH}+16 \Gamma \mathrm{HCCC}+ \\
18 \Gamma \mathrm{HCCC}+25 \Gamma \mathrm{HCCC}\end{array}$ \\
\hline 50 & $1021 \mathrm{w}$ & & 1058 & 1.805 & 1898 & 3.62 & 1033 & 5.23 & $14 v \mathrm{CC}+10 v \mathrm{CC}+11 v \mathrm{CC}+11 \delta \mathrm{HCC}$ \\
\hline 51 & $1045 w$ & & 1070 & 0.87 & 1054 & 1.51 & 1054 & 1.66 & $\begin{array}{c}17 v \mathrm{CC}+10 v \mathrm{CC}+10 v \mathrm{CC}+11 \Gamma \mathrm{HCCC}+ \\
10 \Gamma \mathrm{HCCC}\end{array}$ \\
\hline 52 & $1078 w$ & & 1085 & 132.09 & 1094 & 50.40 & 1095 & 61.23 & $100 \mathrm{CC}$ \\
\hline 53 & $1110 \mathrm{~s}$ & & 1096 & 6.55 & 1102 & 4.03 & 1100 & 5.23 & $10 v \mathrm{CC}+10 v \mathrm{CC}+21 \delta \mathrm{HCC}+16 \delta \mathrm{HCC}$ \\
\hline 54 & & & 1112 & 3.35 & 1144 & 78.29 & 1141 & 94.64 & $10 v \mathrm{CC}+25 \delta \mathrm{HCC}+16 \delta \mathrm{HCC}+24 \delta \mathrm{HCC}$ \\
\hline 55 & $1153 \mathrm{~s}$ & & 1162 & 15.95 & 1155 & 456.73 & 1151 & 467.08 & $\begin{array}{c}12 \mathrm{vNN}+11 \delta \mathrm{HCC}+11 \delta \mathrm{HCC}+11 \delta \mathrm{HCC}+ \\
14 \delta \mathrm{HCC}\end{array}$ \\
\hline 56 & $1169 \mathrm{vs}$ & $1169 w$ & 1166 & 502.23 & 1164 & 11.05 & 1162 & 45.06 & $16 v \mathrm{NN}+19 \delta \mathrm{HCC}$ \\
\hline 57 & & & 1180 & 15.76 & 1180 & 110.30 & 1180 & 95.68 & $23 v \mathrm{NN}+21 v \mathrm{CC}$ \\
\hline 58 & $1206 \mathrm{~s}$ & & 1197 & 110.99 & 1202 & 1.13 & 1200 & 1.01 & $100 \mathrm{CC}+350 \mathrm{NC}+10 \delta \mathrm{HCC}$ \\
\hline 59 & & $1232 w$ & 1217 & 113.43 & 1237 & 755.14 & 1231 & 784.33 & $11 v \mathrm{CC}+24 v \mathrm{NC}+19 \delta \mathrm{HNN}$ \\
\hline 60 & $1247 \mathrm{vs}$ & & 1222 & 238.96 & 1246 & 138.80 & 1241 & 100.88 & $290 \mathrm{CC}$ \\
\hline 61 & $1278 \mathrm{~s}$ & & 1252 & 817.71 & 1269 & 28.32 & 1267 & 23.45 & $11 v \mathrm{CC}+17 \delta \mathrm{HCC}+30 \delta \mathrm{HCC}$ \\
\hline 62 & $1285 \mathrm{~s}$ & & 1265 & 3.70 & 1289 & 17.73 & 1287 & 18.03 & $18 \delta \mathrm{HCC}+11 \delta \mathrm{HCC}+23 \delta \mathrm{HCC}+20 \mathrm{HCC}$ \\
\hline 63 & & & 1291 & 14.20 & 1304 & 6.96 & 1293 & 11.63 & $19 v \mathrm{CC}+17 v \mathrm{CC}+17 v \mathrm{CC}+18 v \mathrm{CC}$ \\
\hline 64 & $1306 \mathrm{~m}$ & & 1316 & 11.77 & 1312 & 20.66 & 1304 & 13.65 & $14 v \mathrm{CC}+21 v \mathrm{CC}+20 v \mathrm{CC}$ \\
\hline 65 & $1358 \mathrm{~s}$ & $1331 w$ & 1379 & 70.08 & 1353 & 64.61 & 1305 & 81.97 & $24 \delta \mathrm{HCH}+37 \delta \mathrm{HCH}+23 \delta \mathrm{HCH}$ \\
\hline 66 & $1379 w$ & & 1401 & 0.28 & 1387 & 0.70 & 1372 & 2.17 & $26 \delta \mathrm{HCH}+42 \delta \mathrm{HCH}+26 \delta \mathrm{HCH}$ \\
\hline 67 & & & 1418 & 44.14 & 1406 & 42.16 & 1402 & 39.82 & $28 v \mathrm{CC}+160 \mathrm{CC}+11 \delta \mathrm{HCC}+12 \delta \mathrm{HCC}$ \\
\hline 68 & & & 1445 & 8.88 & 1426 & 17.03 & 1419 & 8.18 & $19 \delta \mathrm{HCC}+16 \delta \mathrm{HCC}+10 \delta \mathrm{HCH}$ \\
\hline 69 & & $1429 \mathrm{~m}$ & 1447 & 2.24 & 1440 & 12.12 & 1423 & 13.56 & $17 \delta \mathrm{HCH}+43 \delta \mathrm{HCH}+20 \delta \mathrm{HCH}$ \\
\hline 70 & $1432 \mathrm{~s}$ & & 1455 & 9.74 & 1448 & 9.23 & 1432 & 7.50 & $36 \delta \mathrm{HCH}+41 \delta \mathrm{HCH}+17 \Gamma \mathrm{HCCC}$ \\
\hline 71 & & & 1456 & 6.25 & 1450 & 5.23 & 1433 & 10.69 & $40 \delta \mathrm{HCH}+37 \delta \mathrm{HCH}+17 \Gamma \mathrm{HCCC}$ \\
\hline 72 & & & 1471 & 34.59 & 1451 & 31.98 & 1447 & 69.47 & $200 \mathrm{NN}+17 \delta \mathrm{HCH}$ \\
\hline 73 & & & 1494 & 22.00 & 1465 & 32.58 & 1456 & 10.17 & $16 \delta \mathrm{HNN}+12 \delta \mathrm{HCH}$ \\
\hline 74 & $1483 \mathrm{~m}$ & & 1506 & 26.43 & 1474 & 31.70 & 1468 & 30.34 & $18 \delta \mathrm{HCC}+19 \delta \mathrm{HCC}+10 \delta \mathrm{CCC}$ \\
\hline 75 & $1499 \mathrm{~s}$ & & 1542 & 195.16 & 1491 & 68.47 & 1488 & 43.79 & $37 v \mathrm{NN}$ \\
\hline 76 & & & 1601 & 173.63 & 1511 & 345.95 & 1507 & 404.32 & $12 v \mathrm{NN}+14 v \mathrm{NC}+27 \delta \mathrm{HNN}$ \\
\hline 77 & $1521 \mathrm{~s}$ & & 1609 & 17.46 & 1563 & 75.61 & 1560 & 67.89 & $27 v \mathrm{CC}+22 v \mathrm{CC}$ \\
\hline 78 & & & 1622 & 386.33 & 1570 & 14.41 & 1566 & 20.96 & $32 v \mathrm{CC}+11 \delta \mathrm{CCC}$ \\
\hline 79 & $1586 \mathrm{vs}$ & & 1629 & 208.88 & 1591 & 12.10 & 1587 & 17.49 & $15 v \mathrm{CC}+12 v \mathrm{CC}+22 v \mathrm{CC}+19 v \mathrm{CC}$ \\
\hline 80 & $1596 v s$ & $1600 \mathrm{~m}$ & 1687 & 252.33 & 1595 & 473.91 & 1589 & 463.68 & $30 v C C+10 v C C+11 v C C$ \\
\hline 81 & $1659 \mathrm{vs}$ & $1754 w$ & 1780 & 309.67 & 1699 & 191.59 & 1693 & 204.88 & $86 v \mathrm{OC}$ \\
\hline 82 & $2741 \mathrm{vw}$ & $2060 w$ & 2887 & 5.07 & 2930 & 3.25 & 2932 & 3.34 & $43 v \mathrm{CH}+43 v \mathrm{CH}+14 v \mathrm{CH}$ \\
\hline 83 & & $2237 \mathrm{vw}$ & 2888 & 33.26 & 2933 & 28.24 & 2935 & 28.59 & $40 v \mathrm{CH}+31 v \mathrm{CH}+28 v \mathrm{CH}$ \\
\hline 84 & & $2365 \mathrm{vw}$ & 2939 & 26.66 & 2986 & 11.16 & 2986 & 15.72 & $51 v \mathrm{CH}+47 v \mathrm{CH}$ \\
\hline 85 & $2919 \mathrm{vw}$ & $2625 \mathrm{w}$ & 2941 & 18.87 & 2987 & 15.55 & 2988 & 11.08 & $50 v \mathrm{CH}+50 v \mathrm{CH}$ \\
\hline 86 & $2985 w$ & $2774 \mathrm{vw}$ & 2953 & 33.57 & 3004 & 23.56 & 3005 & 24.64 & $22 v \mathrm{CH}+70 v \mathrm{CH}$ \\
\hline 87 & & $3020 \mathrm{vw}$ & 2987 & 22.76 & 3042 & 16.6 & 3040 & 17.19 & $86 \mathrm{vCH}$ \\
\hline 88 & & & 3016 & 4.19 & 3052 & 11.77 & 3055 & 10.09 & $28 v \mathrm{CH}+63 v \mathrm{CH}$ \\
\hline 89 & & $3060 \mathrm{vw}$ & 3020 & 16.27 & 3055 & 11.93 & 3058 & 11.33 & $91 v \mathrm{CH}$ \\
\hline 90 & & & 3028 & 20.68 & 3063 & 16.47 & 3066 & 14.93 & $60 v \mathrm{CH}+11 v \mathrm{CH}+26 v \mathrm{CH}$ \\
\hline 91 & & & 3042 & 37.33 & 3078 & 40.49 & 3080 & 32.93 & $25 v \mathrm{CH}+60 \mathrm{CH}+10 \mathrm{CH}$ \\
\hline 92 & & & 3050 & 13.58 & 3083 & 14.30 & 3086 & 10.66 & $91 v \mathrm{CH}$ \\
\hline 93 & & $3123 \mathrm{vw}$ & 3060 & 0.42 & 3094 & 0.15 & 3091 & 0.10 & $92 v \mathrm{CH}$ \\
\hline 94 & $3040 \mathrm{vw}$ & $3320 \mathrm{vw}$ & 3062 & 5.45 & 3099 & 4.98 & 3100 & 4.33 & $92 v \mathrm{CH}$ \\
\hline 95 & $3065 \mathrm{vs}$ & $3384 \mathrm{vw}$ & 3078 & 3.91 & 3114 & 3.02 & 3114 & 2.29 & $92 v \mathrm{CH}$ \\
\hline 96 & $3217 \mathrm{vw}$ & $3532 \mathrm{w}$ & 3463 & 36.15 & 3344 & 9.79 & 3369 & 10.77 & $100 \mathrm{vNH}$ \\
\hline
\end{tabular}

w-weak; vw-very weak

${ }^{b}$ IRint-IR intensity.

${ }^{c}$ Potential energy distribution (PED) calculated B3LYP/6-311G (d, p). $v$ stretching, $\delta$ : bending, $\Gamma$ : torsion, $\lambda$ : out, PED less than $10 \%$ are not shown.

Egypt. J. Chem. 61, No. 2 (2018) 
TABLE 4. Theoretical and experimental ${ }^{1} \mathrm{H}$ and ${ }^{13} \mathrm{C}$ isotropic chemical shifts (with respect to TMS, all values in ppm) for AMT structure.

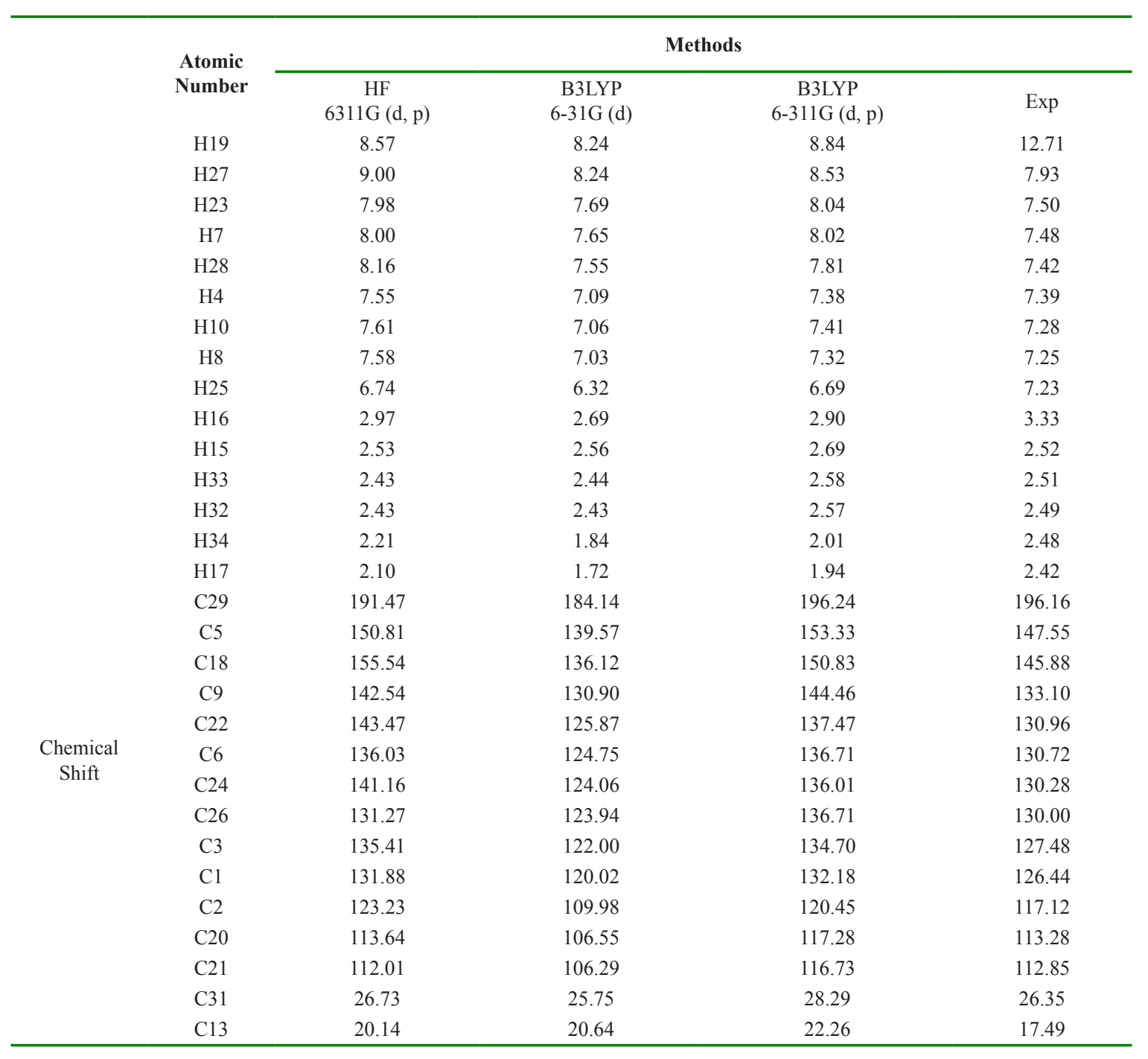

TABLE 5. Correlation between theoretical and experimental methods for NMR property in AMT structure.

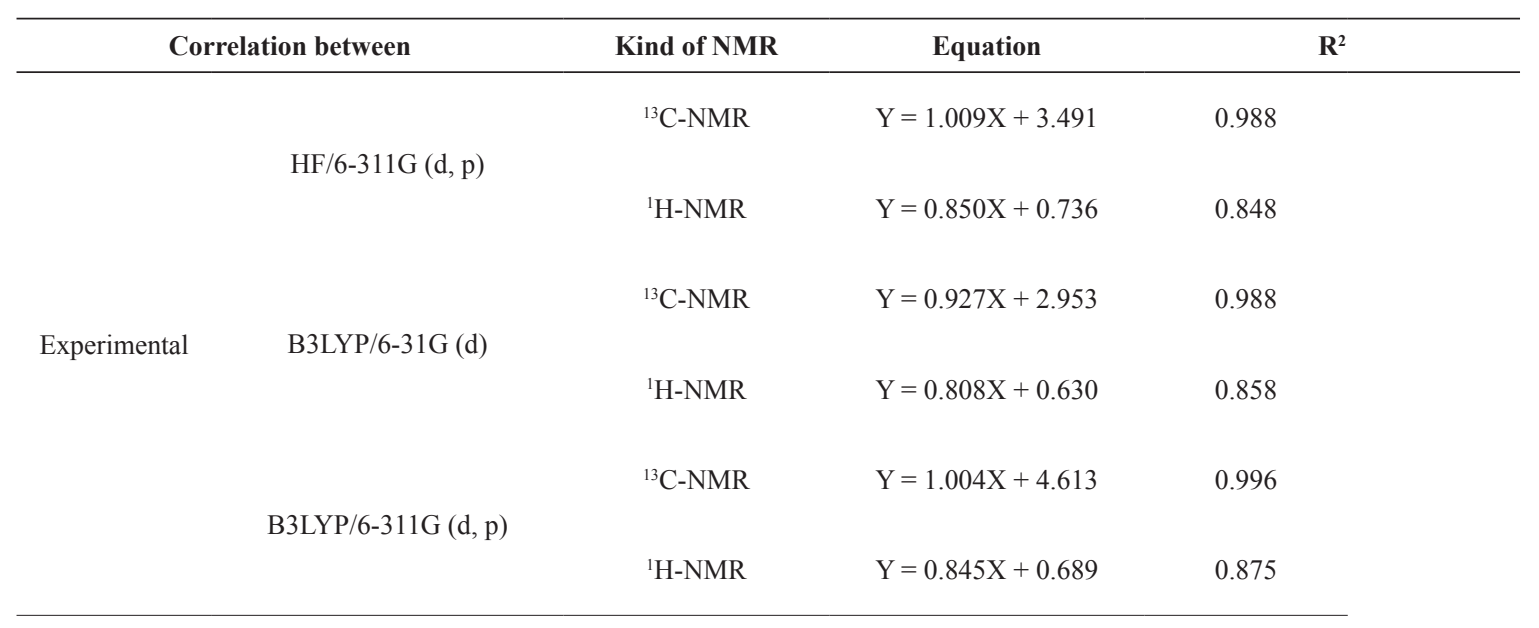


two forms simple and doublet, and it causes to have a different vibration in this region. The FT-IR consideration shows how $\mathrm{N}-\mathrm{N}$ stretching vibration will be very much in $1153 \mathrm{~cm}^{-1}$ and 1169 $\mathrm{cm}^{-1}$ that correspond with obtained amounts by theoretical calculations in level B3LYP/6-311G $(\mathrm{d}, \mathrm{p})$ that shows this vibration amplitude in 1151, 1167 and $1180 \mathrm{~cm}^{-1}$. However for $\mathrm{N}=\mathrm{N}$ stretching vibration was observed in the FT-IR spectrum in $1499 \mathrm{~cm}^{-1}$ with middle intensity. The theoretical calculation in level of B3LYP/6-311G (d, p) theoretical results showed the same amplitude of this vibration in region $1447 \mathrm{~cm}^{-1}$ and 1448 $\mathrm{cm}^{-1}$. However, the bending vibration for $\mathrm{N}-\mathrm{N}=\mathrm{N}$ is observed in (PEDs 15\%) 918 frequency use B3LYP/6-311G (d, p) method.

\section{NMR spectra}

The obtained results for chemical shift, ${ }^{13} \mathrm{C}-\mathrm{NMR}$ and ${ }^{1} \mathrm{H}-\mathrm{NMR}$ amounts were reported in Table 4. The obtained amounts calculated theoretically using GIAO method, and these calculations were spotted in three theoretical levels B3LYP/6-311G (d, p), B3LYP/6-31G (d) and $\mathrm{HF} / 6-311 \mathrm{G}(\mathrm{d}, \mathrm{p})$. TMS was spotted as a reference for the obtained results and be closer to the experimental amounts. Thus, the TMS chemical shift amounts were calculated individually using the above methods and were obtained the results for the AMT structure based on that. After the calculation, compared the theoretical and experimental amounts, and obtained a diagram for each method. Linear equation amounts reported in Table 5. But noteworthy point in this spectrum is $\mathrm{H} 19$ peak indication in region $12.7 \mathrm{ppm}$ for the experimental spectrum. That by perform HF/6$311 \mathrm{G}(\mathrm{d}, \mathrm{p}), \mathrm{B} 3 \mathrm{LYP} / 6-31 \mathrm{G}(\mathrm{d})$ and B3LYP/6-311G $(\mathrm{d}, \mathrm{p})$ theoretical methods the amount of chemical shift was obtained respectively in region 8.57, 8.24 and $8.84 \mathrm{ppm}$. However, for formamidines the chemical shift amounts indicated in region 7 to $8 \mathrm{ppm}$ for this type of hydrogen $[49,50]$. But for compounds with three adenine groups the different experimental results showed that due to difference of chemical environment of this hydrogen, the chemical shift is appeared in lower region or be deshield (Fig 6 and 7). To explain this discrepancy, is stated that such theory calculations and other NMR results were performed in gas phase, while the experimental calculations were done in solution phase. It represents that the chemical shift amounts are under effect of solvent experimentally.

\section{Molecular electronic potential maps}

First, the AMT structure was optimized by

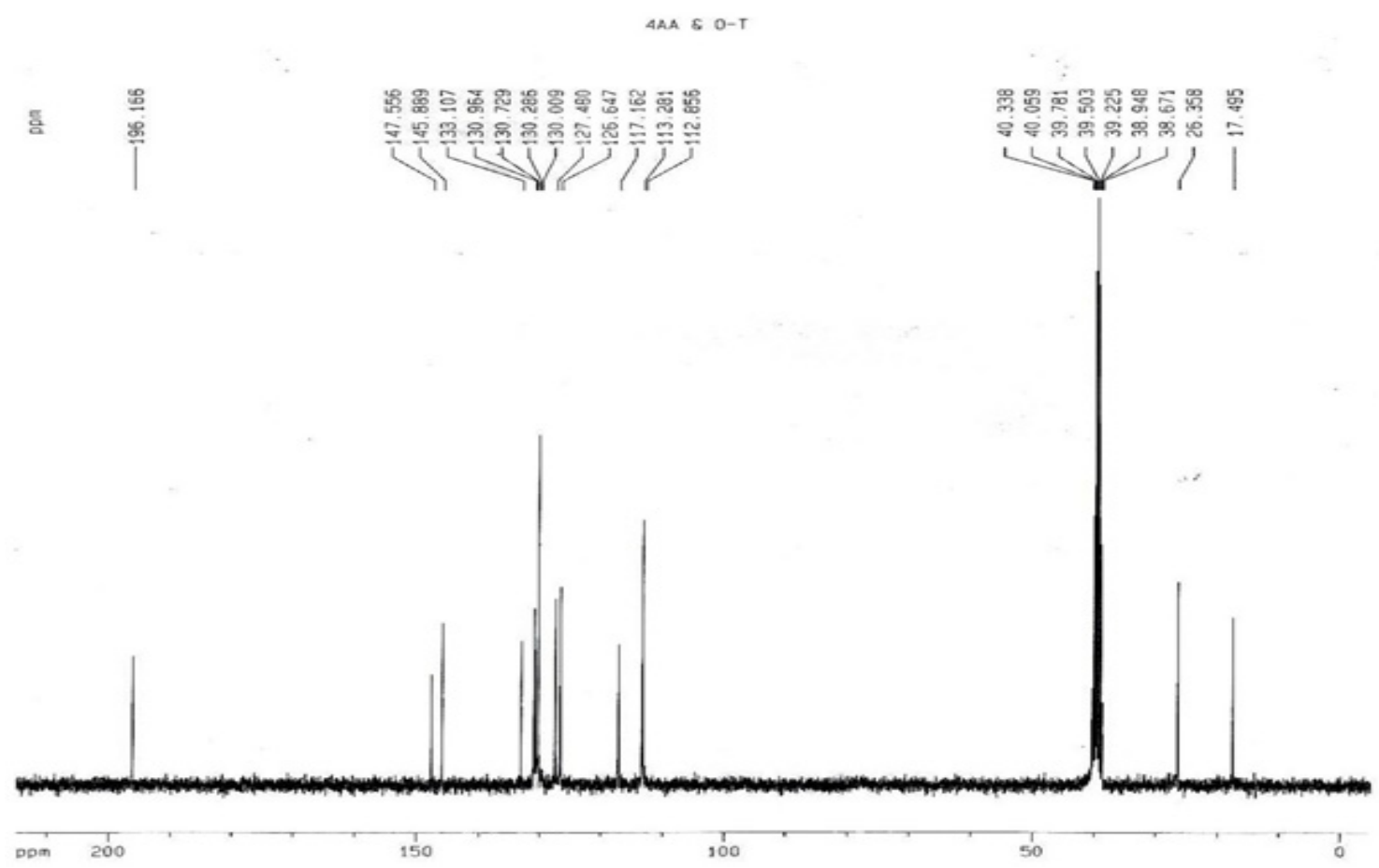

Fig. 6. Show and comparison 13C-NMR spectrum obtained by experimental methods for the title compound. 


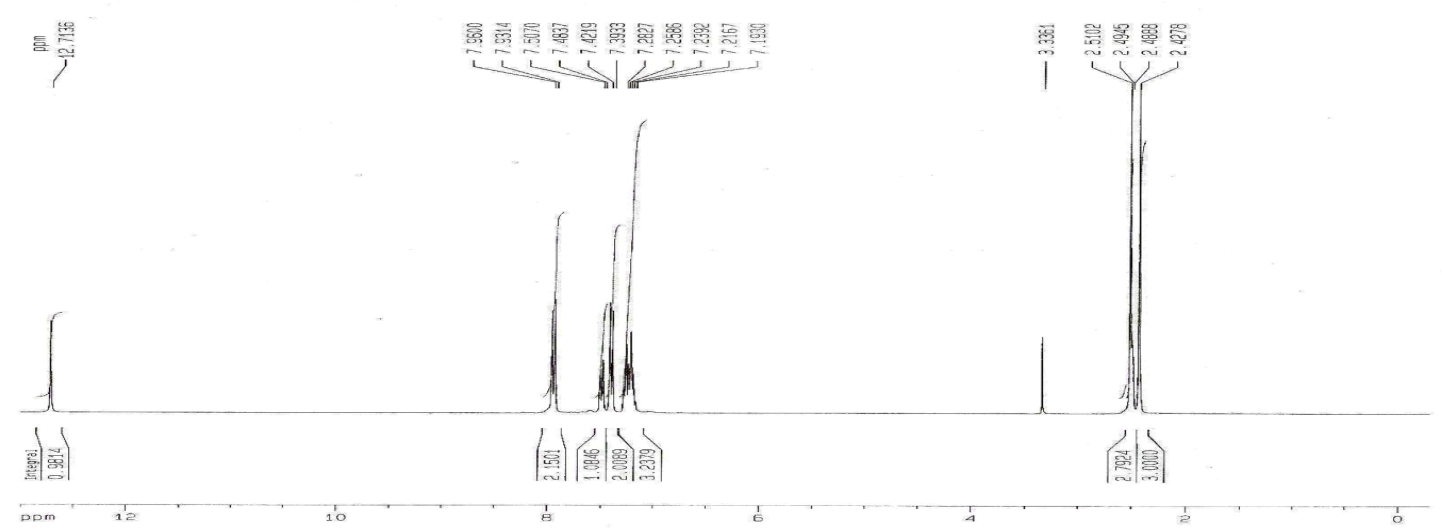

Fig. 7. Show and comparison ${ }^{1} \mathrm{H}-\mathrm{NMR}$ spectrum obtained by experimental methods for the title compound.

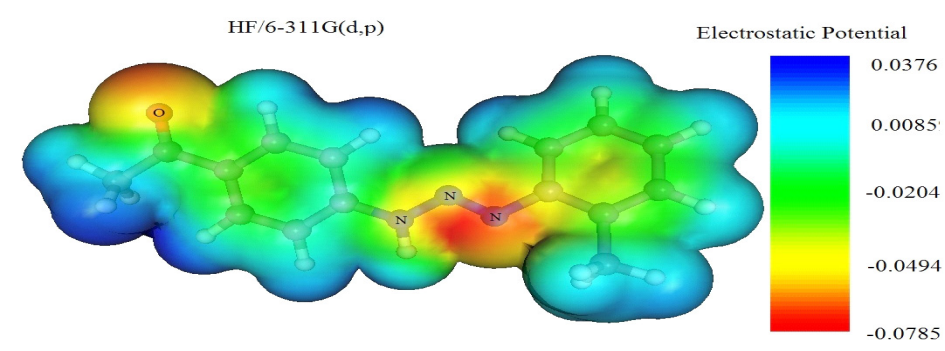

(a)

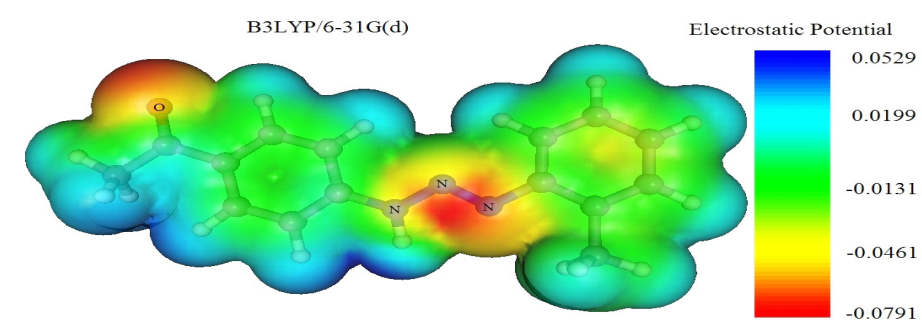

(b)

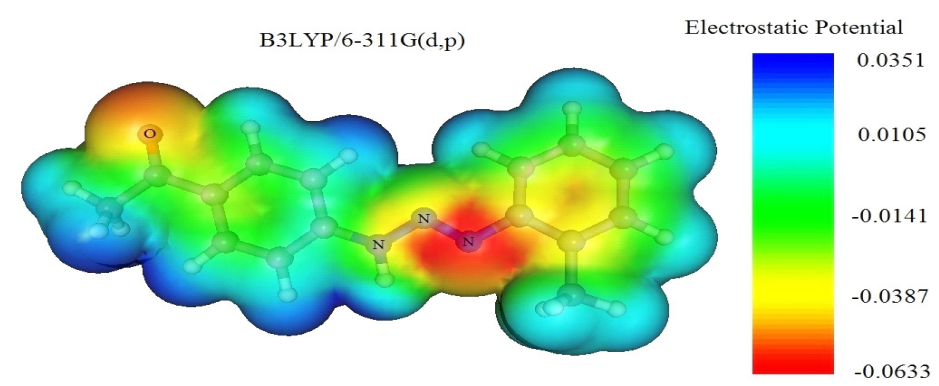

(c)

Fig. 8. (a) HF/6-311G (d, p), (b) B3LYP/6-31G (d) and (c) B3LYP/6-311G (d, p) calculated 3D molecular electrostatic potential of ATM (isosurface value 0.01 a.u.). 
B3LYP/6-311G (d, p) method for calculated electronic potential amounts, then calculated the electronic potential amounts in structure [56-60]. Molecular electronic potential maps (MEPM) in fact determine conditions that present the most electrophilic attack probability to these points and they are reactivity value detector of various parts of molecule. As Fig. 8 shows, the electronic potential value is increased by going to blue color, and it decreased by going to red color. The electronic potential value had a negative amount in apart that Oxygen exist, in areas that present also Carbonic groups, the electronic potential is closed to positive amounts namely the blue color.

\section{Other molecular properties}

The thermo dynamical parameters, dipole moment and other energetic parameters were reported in Table 6. For this purpose, three methods HF/6-311G (d, p), B3LYP/6-31G (d) and B3LYP/6-311G (d, p) were used. All parameters were calculated in gas phase and the temperature of 298.15 kelvin degrees, and the pressure of one atmosphere, also the calculation of some associated to HOMO and LUMO levels parameters such as chemical hardness $(\eta)$, chemical potential $(\mu)$, electrophilicity $(\omega)$ and max amount of electronic charge transfer $\left(\Delta \mathrm{N}_{\max }\right)$ was gestured in this table.

\section{Conclusions}

First, the AMT structure was synthesized by assigned crystallography method in laboratory and for its recognition, was used ${ }^{1} \mathrm{H}-\mathrm{NMR}$, ${ }^{13} \mathrm{C}-\mathrm{NMR}$, FT-IR, FT-Raman and X-ray single crystal diffraction methods, then considered the thermodynamically parameters, chemical shift value and also the vibrational frequencies using HF/DFT theoretical methods with 6-311G (d, p) and $6-31 \mathrm{G}(\mathrm{d})$ basis sets, thus the structure was improved, then calculated the parameters. Three scaled factor of transfer coefficient $0.909,0.960$ and 0.967 were used for three methods $\mathrm{HF} / 6-311 \mathrm{G}$ (d, p), B3LYP/6-31G (d) and B3LYP/6-311G $(d, p)$ for more corresponding of the theoretical and experimental obtained results. However, the vibrational spectra were analyzed using $V E D A$ 4 software and the value of Potential energy distributions was considered, then the theoretical and experimental results were compared, the obtained results showed the theoretical amounts were closed to experimental results and they correspond to each other completely. The theoretical method B3LYP/6-311G (d, p) showed the most corresponding with the obtained experimental results, from three performed theoretical methods.

TABLE 6. Theoretically computed energies (kcal.mol-1), zero-point vibrational energies (kcal.mol-1), rotational constants (GHz), heat capacities (cal.mol-1.K-1), entropies (cal.mol-1.K-1), dipole moment (Debye), molecular orbitals energies ( $\varepsilon \mathrm{HOMO}$ and $\varepsilon \mathrm{LUMO}, \mathrm{eV})$, electronic chemical potential, $\mu(\mathrm{eV})$, chemical hardness, $h(\mathrm{eV})$, electrophilicity, $\omega(\mathrm{eV})$ and maximum amount of electronic charge transfer for AMT structure.

\begin{tabular}{cccc}
\hline Parameters & HF/6-311G(d,p) & B3LYP/6-31G $(\mathrm{d})$ & B3LYP/6-311G(d,p) \\
\hline Total energy & -511303.316 & -514430.903 & -514561.463 \\
ZPVE & 182.25362 & 171.54501 & 170.34596 \\
Rotational constant & 1.26256 & 1.28386 & 1.28610 \\
& 0.12369 & 0.12073 & 0.12099 \\
Entropy & 0.11384 & 0.11054 & 0.11086 \\
Total & 134.848 & 140.669 & 140.100 \\
Translational & 42.487 & 42.487 & 42.487 \\
Rotational & 34.158 & 34.194 & 34.188 \\
Vibrationa1 & 58.204 & 63.988 & 63.426 \\
& & & \\
Heat capacity & 61.675 & 65.739 & 65.940 \\
Dipole moment(D) & 3.9404 & 3.7862 & -0.21813 \\
HOMO & -0.29470 & -0.20884 & -0.08090 \\
LUMO & 0.07248 & -0.07194 & -0.14951 \\
Chemical & -0.11111 & -0.14039 & \\
potential $(\mu)$ & & & 0.13723 \\
Chemical & 0.36718 & 0.13690 & \\
hardness $(\eta)$ & & & 0.08144 \\
Electrophilicity $(\omega)$ & 0.01681 & 0.07198 & 1.08952 \\
$\Delta N_{\max }$ & 0.30260 & 1.02549 &
\end{tabular}

Egypt. J. Chem. 61, No. 2 (2018) 


\section{Acknowledgements}

The authors are indebted to Ms Esfandiar for his interest in this work and many helpful discussions. However, this work was supported by Islamic Azad University, Shahre-rey Branch.

\section{References}

1. Ang H. G., Koh L. L., Yang G. Y., J. Chem. Soc., Dalton Trans. 1573 (1996).

2. Rouzer C. A., Sabourin M., Skinner T. L., Thompson E. J., Wood T. O., Chmurny G. N., Klose J. R., Roman J. M., Smith Jr. R. H., Michejda C., J. Chem. Res. Toxicol, 9, 172 (1996).

3. Nicolau K. C., Boddy C. N. C., Li H., Koumbis A. E., Hughes R., Natarajan S., Jain N. F., Ramanjulu J. M., Bra"se S., Soloman M., Chem. Eur. J, 5, 2602 (1999).

4. Jones L., Schumm J. S., Tour J. M., J. Org. Chem, 62, 1388 (1997).

5. Jian H., Tour J. M., J. Org. Chem, 70, 3396 (2005).

6. Lippert T., Nuyken O., Makromol. Chem., Rapid Coтmun, 13, 365 (1993).

7. Wanner M. J., Koch M., Koomen G. J., J. Med. Chem, 47, 6875 (2004).

8. Monica Barra N.C., Lee I., Chahal N., J. Org. Chem, 672271 (2002)

9. Buruiaba E., Melinte V., Buruiana T., Simionescu B., Lippert T., Urech L., J.Photo. Chem. 44, 5271 (2006).

10. Safavi A., Haghihi B., Frescnius J., J. Anal. Chem. 357, 870 (1997).

11. Rofouei M.K., Aghaei A., J. Iran. Chem. Soc. 10,969 (2013).

12. Gholivand M.B., Mohammadi M., Khodadadian M., Rofouei M.K., Talanta 78922 (2009).

13. Gholivand M.B., Mohammadi M., Rofouei M.K., Mater. Sci. Eng. C 30, 847 (2010).

14. Rofouei M.K., Payehghadr M., Shamsipur M., Ahmadalinezhad A., J. Hazard. Mater. 168, 1184 (2009).

15. Rofouei M.K., Sabouri A., Ahmadalinezhad A., Ferdowsi H., J. Hazard. Mater. 192, 1358 (2011).

16. Hill D.T., Stanley K.G., Williams J.E., Love B., P.J. Fowler, McCafferty J.P., Macko E., Berkoff C.E.,
Ladd C.B., J. Med. Chem. 26, 865 (1983).

17. Brahimi F., Rachid Z., McNamee J.P., AlaouiJamali M.A., Tari A.M., Jean-Claude B.J., Biochem. Pharmacol. 70, 511 (2005).

18. Jean-Claude B.J., Mustafa A., Damian Z., De Marte J., Vasilescu D.E., Yen R., Chan T.H., Leyland Jones B., Biochem. Pharmacol. 57753 (1999).

19. Friedman H.S., Kerby T., Calvert H., Clin. Cancer Res. 6, 2585 (2000).

20. Agarwala S.S., Kirkwood J.M., Oncologist 5, 144 (2000).

21. Nicolaou K.C., Boddy C.N.C., Li H., Koumbis A.E., Hughes R., Natarajan S., Jain N.F., Ramanjulu J.M., Bräse S., Solomon M.E., Chem. Eur. J. 5, 2602 (1999).

22. Lazny P., Sienkiewicz M., Brase S., Tetrahedron 57, 5825 (2001).

23. Knochel P., Liu C.Y., Org. Lett. 7, 2543 (2005).

24. Kimball D.B., Weakley T.J.R., Herges R., Haley M.M., J. Am. Chem. Soc. 124, 13463 (2002).

25. Dabbagh H.A., Teimouri A., NajafiCh A., Shiasi R., Spectro. Chim.ActaPart A. 67, 437 (2007).

26. Boeringer Sohn C.H., German Offen. 2, 301 (1974).

27. Eleventh Report on Carcinogens (2004).

28. Rofouei M.K., Soleymani R., Aghaei A., Mirzaei M., Journal of Molecular Structure, 1125, 247 (2016).

29. Immirzi A., Porzio W., Bombieri G., Toniolo L., $J$. Chem. Soc. Dalton Trans. 1098 (1980).

30. Melardi M.R., Rofouei M.K., Massomi J., Anal. Sci. 23, x67 (2007).

31. Bourissou D., Guerret O., Gabba1 F. P., Bertrand G., Chem. Rev, 100, 39 (2000).

32. Horner M., de Oliveira G. M., Bresolin L., de Oliveira A. B., Inorg. Chim.Acta.359, 4631 (2006).

33. Marchesi F., Turriziani M., Tortorelli G., Avvisati G., Torino F., DeVecchis L., Pharmacological Research. 56, 275 (2007).

34. Lehn J.M., Science. 260, 1762 (1993).

35. Stupp S.I., Lebonheur V., Walker K., Li L.S., Hugging K.E., Kesser M., Amstutz A., Science. 276, 276 (1997). 
36. Dalgarno S.J., Power N.P., Atwood J.L., Coord Chem..Rev. 252, 825 (2008).

37. Parr R.G., Szentpaly L.V., Liu S., J. Am. Chem. Soc. 121, 1922 (1999)

38. Chamorro E., Duque-Norea M., Perez P., J. Mol. Struct. 896, 73 (2009).

39. Sheldrick G. M., ActaCryst., A. 64,112 (2008).

40. Spek A.L., PLATON, A Multipurpose Crystallographic Tool, Utrecht University, Utrecht, Netherlands (2005).

41. Mercury 1.4.1, Copyright Cambridge Crystallographic Data Centre, 12 Union Road.

42. Ganjali M.R., Rouhollahi A., Mardan A.R., Shamsipur M., J. Chem. Soc., Faraday Trans. 94, 1959 (1998).

43. Fakhari A., Shamsipur M., J. Inclusion Phenom. 26, 243 (1996).

44. D. M. Khramov, C. W. Bielawski, J. Org. Chem. 72 (2007) 9407.

45. Frisch M.J., Trucks G.W., Schlegel H.B., Scuseria G.E., Robb M.A., Cheeseman J.R., Montgomery J.A., Vreven T., Kudin K.N., Burant J.C., Millam J.M., Iyengar S.S., Tomasi J., Barone V., Mennucci B., Cossi M., Scalmani G., Rega N., Petersson G.A., Nakatsuji H., Hada M., Ehara M., Toyota K., Fukuda R., Hasegawa J., Ishida M., Nakajima T., Honda Y., Kitao O., Nakai H., Klene M., Li X., Knox J.E., Hratchian H.P., Cross J.B., Adamo C., Jaramillo J., Gomperts R., Stratmann R.E., Yazyev O., Austin A.J., Cammi R., Pomelli C., Ochter ski J.W., Ayala P.Y., Morokuma K., Voth G.A., Salvador P., Dannenberg J.J., Zakrzewski V.G., Dapprich S., Daniels A.D., Strain M.C., Farkas O., Malick D.K., Rabuck A.D., Raghavachari K., Foresman J.B., Ortiz J.V., Cui Q., Baboul A.G., Clifford S., Cioslowski J., Stefanov B.B., Liu G., Liashenko A., Piskorz P., Komaromi I. , Martin R.L., Fox D.J., Keith T. , Al-Laham M.A., Peng C.Y., Nanayakkara A., Challacombe M., Gill P.M.W., Johnson B., Chen W., Wong M.W., Gonzalez C., Pople J.A, Gaussian 03 Revision C.02, Gaussian Inc.,Pittsburgh, PA, (1998).
46. Dennington R., Keith T., Millam J., Eppinnett K., Lee Hovell W., Gilliland R.,Gauss View, Version 3. 07, Semichem, Inc., Shawnee Mission, KS, (2003).

47. Wolinski K., Hinton J.F., Pulay P., J. Am. Chem. Soc. 112, 8251 (1990).

48. Jamroz M.H, Vibrational Energy Distribution Analysis VEDA 4, Warsaw, (2004).

49. Rofouei M.K., Sohrabi N., Shamsipur M., Fereyduni E., Ayyappan S., Sundaraganesan N., Spectrochimica Acta Part A. 76, 182 (2010).

50. Rofouei M.K., Fereyduni E., Sohrabi N., Shamsipur M., Attar Gharamaleki J., Sundaraganesan N., Spectrochimica Acta Part A. 78, 88 (2011).

51. Arjunan V., Mythili C.V., Mageswari K., Mohanc S., Spectrochimica Acta Part A. 79, 245 (2011).

52. Hakan Arslan, Ulrich Fl"orke, Nevzat K"ulc"u, G"un Binzet, SpectrochimicaActa Part A. 68, 1347 (2007).

53. Shimanouchi T., Kakiuti Y., Gamo I., J. Chem. Phys. 25, 1245 (1956).

54. Tsuboi M., Spectrochim. Acta A. 16, 507 (1960).

55. Saxena R., Kauedpal L.D., Mathur G.N., J. Polym. Sci. A: Polym. Chem. 40, 3559 (2002).

56. Politzer P., Truhlar D.G. (Eds.), Chemical Application of Atomic and Molecular Electrostatic Potentials, Plenum, New York, (1981).

57. Soleymani R., Mohammad Salehi Y., Yousofzad T., Karimi-Cheshmeh Ali M., Oriental Journal of Chemistry 28, 627 (2012).

85. Soleymani R., Dijvejin R.D., Hesar A.F.G.A., Sobhanie E., Oriental Journal of Chemistry, 28, 1291 (2012).

59. Soleymani R., Dijvejin R.D., Hesar A.F.G.A., Oriental Journal of Chemistry, 28, 1107 (2012).

60. Zarei G., Soleymani R., Dejvejen R. D., Oriental Journal of Chemistry, 28, 1229 (2012).

(Received 27/11/2017; accepted 22/ 2 /2018) 